\title{
America's Name Baptized on a Globe in 1510. Leonardo da Vinci's Blueprint for the Jagiellonian Armillary Sphere Discovered.
}

\author{
Stefaan Missinne \\ Professor, Fellow of the Royal Geographical Society, London, UK \\ Email: missinne@aon.at
}

How to cite this paper: Missinne, S. (2021). America's Name Baptized on a Globe in 1510. Leonardo da Vinci's Blueprint for the Jagiellonian Armillary Sphere Discovered. Advances in Historical Studies, 10,93-133. https://doi.org/10.4236/ahs.2021.101008

Received: January 10, 2021

Accepted: March 26, 2021

Published: March 29, 2021

Copyright $\odot 2021$ by author(s) and Scientific Research Publishing Inc. This work is licensed under the Creative Commons Attribution International License (CC BY 4.0).

http://creativecommons.org/licenses/by/4.0/ (c) (i) Open Access

\begin{abstract}
The treasure room at the Collegium Maius of the Jagiellonian Museum in Cracow contains an armillary sphere dating from 1510. This scientific object of excellent French workmanship contains the Jagiellonian Globe, which looks surprisingly like the Lenox Globe, a sibling of the da Vinci Globe. The fact that the Jagiellonian Globe is mounted in an armillary sphere supports the hypothesis that the Lenox, cast from reddish copper, was most likely the central part of a lost armillary sphere. A horologist copied the cartography of the Lenox Globe. It is hypothesized that he also copied the decorative artistic design of the armillary sphere as a blueprint. Using primary data in his research, the author describes the compelling Jagiellonian instrument. He concentrates on aspects of epigraphy, toponymy, orthography, iconography, cosmography, ornamental history, visual arts, heraldry, kinematics, geometry, didactics and astronomy. The methodology used is based on analogy in the arts, stemmatics, cartographic, historiographical and comparative analysis based on the latest 3D photographic scanning technology of the Lazarus Project of the University of Rochester. Furthermore, more than 40 international experts and researchers contained in the list of acknowledgements assisted in making this research possible. The author attributes the Jagiellonian Globe to Jean Coudray, Early Modern horologist active for successive French Kings in Blois. This is substantiated by a monogram. It is a capital letter $\mathrm{C}$ next to a reversed half-Moon on the bottom of the Jagiellonian Globe. The author provides key evidence that this French horologist constructed the instrument between 1507 and 1510 based on a model armillary sphere. In making the Jagiellonian, Jean Coudray added the latest cartographic news in the form of a Latin phrase "America noviter reperta" thereby baptizing the name of America for the first time in Early Modern history on a three-dimensional object. Compelling arguments and chronological evidence are offered by the orthography, nomenclature, applied old French dimensions, iconography of the instrument and
\end{abstract}


the unique cartography of the terrestrial globe contained at its center. The specific didactic scheme of this universal armillary sphere, in addition to the whirlpools adjacent to the orb, bear the visual signature of Leonardo da Vinci. However, the French horologist was not only influenced by stylistic Renaissance and didactical aspects used by Leonardo. He copied them. These include the mirroring of the Roman numerals and of the order of the hour band on the Equator reflecting the concaveness of the object based on a Vitruvian design. In addition, the unique design of the throne of the armillary sphere is influenced by Leonardo's kinetics. The two scrolls of the throne contained in a newly developed design, in this case one of life-giving whirlpools, echoes the kinetic untamed energy and power of nature and of the oceans in particular. The iconography of the world sphere, the cosmic egg, in between the two scrolls means perfection, the primordial form which contains all the possibilities of all the forms as Plato's animus mundi, the soul of the world. The anonymous large mountainous island mirroring the Regio Pathalis of Pliny and Bacon is used in the cartography of the da Vinci, Lenox and Jagiellonian Globe. Finally, the author offers evidence of a bibliographical reference to a specific astronomical clock instrument just like the Jagiellonian Armillary Sphere. This reference is listed in a contemporary French inventory of the famous Florimond Robertet, notorious client of Leonardo da Vinci, dating from 1532.

\section{Keywords}

Leonardo da Vinci, Jagiellonian Armillary Sphere, da Vinci Globe, Lenox Globe, Jean Coudray, Florimond Robertet

\section{Introduction}

During the research on the da Vinci Globe, made of two conjoined ostrich egg halves, I came upon the Jagiellonian Armillary Sphere, in short, Jagiellonian, a Renaissance Earth-centered Ptolemaic Model of the Universe, kept in Cracow and dating from 1510. This scientific object of excellent workmanship contains the Jagiellonian Globe. The latter surprisingly looks like the Lenox Globe (Missinne, 2018), but its artistic historical significance as a sibling of the Leonardo da Vinci and Lenox Globe has to date been neglected. A French origin of the Jagiellonian was suggested but this was never proven. Stevenson compared the Lenox to the Jagiellonian Globe and stated that they appear to be the work of the same globe maker or copies of a common original (Stevenson, 1921).

The fact that the Jagiellonian Globe is mounted in an armillary sphere supports the hypothesis that the Lenox, cast from reddish copper, was most likely the central part of a lost armillary sphere. The Lenox and the contemporary Jagiellonian Globe contained in an armillary sphere seem to be copies of a common original, as Estreicher suggested in his work (Estreicher, 1900).

A careful examination of the Jagiellonian raises some unanswered questions. If this armillary sphere was constructed only a few years after the da Vinci and 
the Lenox Globe, would it be possible that the Jagiellonian reflected decorative and other underlying aspects of the now lost armillary sphere which contained the Lenox Globe at its center?

What is the subject matter of this object, and how should one interpret the different iconographic motifs? In what follows, I try to reach an understanding of its historical context and the time it was made, comparing images and contextual materials from the time with subsequent instruments. Was it commissioned by a patron? Can its attribution be based on indirect evidence?

Based on the fact that an anonymous horologist, or member of a workshop, who made the Jagiellonian, thus copied the cartography of the Lenox Globe, it is reasonable to assume that he also copied the decorative artistic design of the armillary sphere containing the globe. So, the question is, what opportunity does this Jagiellonian offer us to look back through the open window at the history of scientific instrument making? Are there any notable traces which lead to the now lost Renaissance armillary sphere which contained the Lenox Globe? And as the construction of an armillary sphere, a so-called sphaera materialis (Dalché, 2010) containing a globe and not the mere construction of a terrestrial globe alone received the most symbolic significance due to the Portuguese overcoming of the challenge to cross the Equator connecting the Northern and Southern Hemisphere during the second half of the 15th Century (Vogel, 1996), would this mean that the importance of the Jagiellonian Armillary Sphere has been underestimated?

In this research, I describe the compelling Jagiellonian, an analytic device of adjustable circles with the globe at its center. Aspects of epigraphy, toponymy research, orthography, iconography, cosmography, ornamental history, visual arts, heraldry, kinematics, geometry, didactics and astronomy are looked at. The methodology used is based on analogy in the arts, stemmatics, cartographic, a historiographical analysis and comparative analysis based on the latest $3 \mathrm{D}$ photographic scanning technology. Numerous field trips were made. In addition, interviews with world-leading experts listed in the acknowledgements were completed in 2019.

I offer evidence that the French horologist who constructed this instrument between 1507 and 1510 used another instrument as a model. Finally, I offer notable substantial evidence that the design and content of the Jagiellonian Armillary Sphere and its central globe were influenced by Leonardo da Vinci.

\section{Description of the Jagiellonian Instrument, its Prove- nance and Iconographic Motifs}

Although the unsigned Jagiellonian Armillary Sphere has a stand from the Regency era dating from 1820-1830 as can be seen in Figure 1, however it was, due to its handle being attached to the North-axis, a hand-held hanging instrument or suspension loop known as an Armillar Suspensoria. Thereby it made it among the first recorded armillary spheres (Zinner 1956) of which only two such 


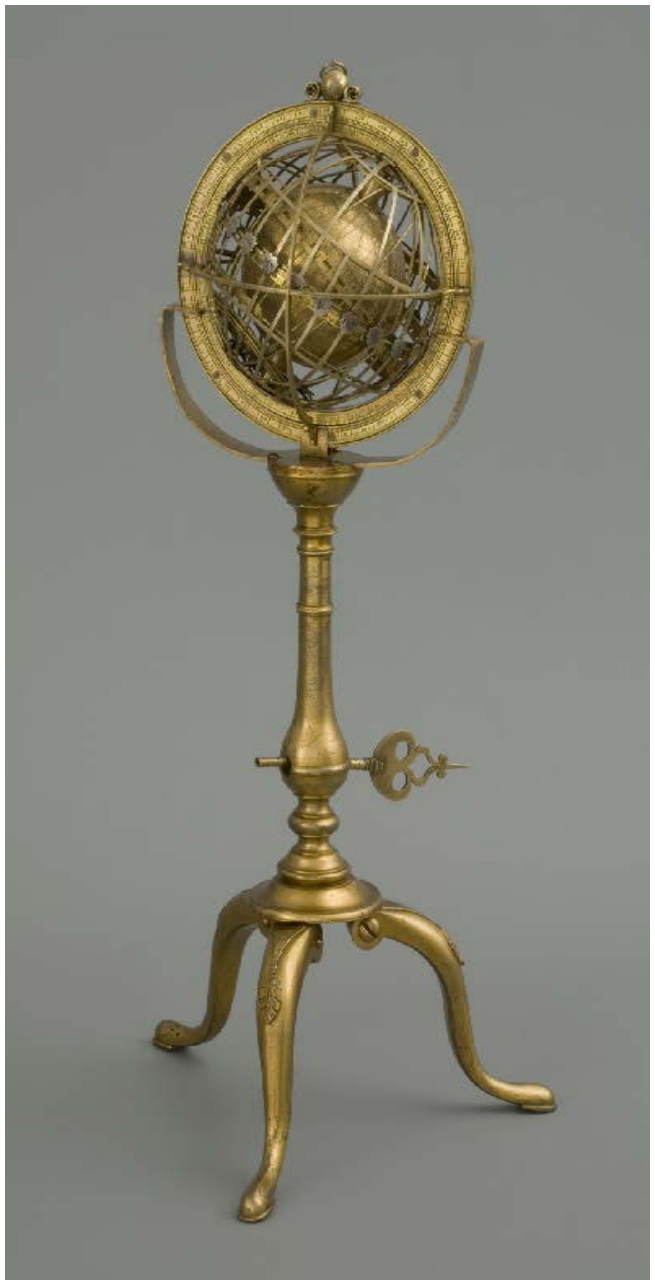

Figure1. The Jagiellonian Armillary Sphere. Picture courtesy of G. Zygier 2018.

examples are believed to have survived (Kugel, 2002): One instrument at the Conservatoire National des Arts et Métiers in Paris and one late Medieval sphere; the latter being a hand-held static sphere originally mounted on a handle, reminiscent of the hand-held armillary sphere design of Johannes de Sacro Bosco's de Sphaera Mundi (c. 1230) at the Whipple Museum of the History of Science in Cambridge dating from ca. 1425 (Dekker, 2007). But, neither of the two foregoing has a decorative handle, known as a throne.

Ptolemy calls the astrolabe that consists of six rings an astrolabon. Its construction is described in the Almagest. It is an assemblage of rings (armilla) representing a number of great circles with the Earth as the center and smaller circles with other centers, for graphically demonstrating the orbits and positions of celestial bodies. There is a fixed meridian ring inside which the ecliptic ring and the solstitial colure are pivoted. Furthermore, two latitude rings are attached, one outside the solstitial colure and the other inside it. Colure in astronomy is either of the two principal meridians of the celestial sphere. Inside the inner ring is added another ring which is equipped with two sighting plates at diametrically opposite points so planetary positions can also be measured 
(Seemann, 1929). No remains are known to exist of any armillary sphere for indicating the movements of the Sun, Moon and planets, nor of any attempt at a precession globe of the type described by Ptolemy (Savage-Smith, 1985).

The Jagiellonian instrument Inv. Nr. 4110-100/V (Zakrzewska, 1965)is a type of astronomical clock (Bertele, 1961). The medium of the instrument is gilded brass, and of the manuscript globe it is heavily gilded copperplate (Babicz, 1970). The scale of the Jagiellonian globe is $1 / 173.500 .000$.

In some areas on the globe there are traces of significant corrosion. According to the expert James Constable in a personal communication, in some cases the copper gilding is done 20 or more years later than the copper cladding. Furthermore, inconsistent revision seems to have been applied and some heavily gilded areas appear to have been retouched. This type of material has physical properties whereby errors can hardly be corrected. The techniques used to apply the letters and numbers on the globe and the instrument seem to be rather inconsistent, combining engraving and punching. The total height of the instrument, including the stand of the Regency era is $42 \mathrm{~cm}$. The diameter of the armillary sphere is $13 \mathrm{~cm}$ (4 pouce, 10 ligne). Pouce (inch) and ligne (line) are old French units of length. These French measurements are important to test the potential evidence in support for a French origin of the construction of this instrument. The matching of these measurements with the historic French units of length confirm for the first time the French origin of the armillary sphere in contrast to the Lenox and the da Vinci Globe. The Jagiellonian globe, consisting of two conjoined halves has a diameter of $7.35 \mathrm{~cm}$ (2 pouce, 8 ligne) which reflects $2 / 3^{\text {rd }}$ of the dimension of the Italian Renaissance globe, called the Lenox, of $11.2 \mathrm{~cm}$ which is $1 / 5$ of a Florentine braccio da terra. Interestingly this reduction in scale supports an increased artistic interest in miniaturization.

If $13 \mathrm{~cm}$, the diameter of the Jagiellonian Armillary Sphere, may perhaps be considered $2 / 3^{\text {rd }}$ of the original now lost Lenox Armillary Sphere, this would mean the Lenox fits into the center of an armillary sphere the size of ca. 7 Florentine soldi (one soldi is $1 / 20^{\text {th }}$ of a Florentine braccio) or ca. $19.5 \mathrm{~cm}$ in order to keep the same proportions.

It is significant to mention that remainders of the casting of the Lenox were found. These visible traces of chalk of Paris, like fine traces of spolvero (Cotte\&Simonot, 2020), were detected on the surface of the Lenox Globe thanks to its detailed scan made available to the public by the New York Public Library in 2018. No remainders of any kind of casting process were found on the surface of the Jagiellonian Armillary Sphere nor on its highly detailed central globe.

The level of detail on the Lenox Globe is very high as the dimension of the engraving of its model, the da Vinci Globe is only one 10th of a millimeter. Numerous black dots probably used for purposes of proportionality and to increase the level of detail were detected on the surface of the da Vinci Globe (Missinne, 2018).

The depiction of the continents, islands, archipelagos, mountain ranges and certain rivers on the Jagiellonian Globe is largely copied from the Lenox Globe. 
But monsters, a multitude of hatched mountains, certain lakes, the drowning sailor, the 1494 treaty line of Tordesillas, the Cape Verde islands, the mingling ocean currents, etc. and any kind of flag proclaiming discovery by a European nation commonly used on contemporary portolan charts are omitted on the Jagiellonian Globe (Figure 2).

Only the engraving of a single small fishing boat visible in the location of the Island of Cyprus in the Eastern Mediterranean could recently, thanks to the recent 3D scanning of the Jagiellonian be detected. The clockmaker may have been inspired by a similar vessel to the West of Corsica on the Lenox Globe and engraves this vessel instead of the island of Cyprus.

It is not insignificant that the position of Ferro is used for the prime meridian on the Jagiellonian Globe. This prime meridian had been known since antiquity. On the da Vinci and on the Lenox Globe the prime meridian and all other linear meridians and parallels for that matter are omitted.

The choice for the location of the division of the globe so as to accommodate a clock was not applied horizontally on the Equator as one might have expected. The division was made vertically on the $170^{\text {th }}$ and $350^{\text {th }}$. The foregoing seemingly symbolically close to the area and reminiscent of the recent division of the world between the Portuguese and the Spanish.

The provenance of the Jagiellonian leads to the collection of the Polish savant Professor Jan Brozek (1585-1652), known for his studies on Copernicus. This scientific instrument was listed as a gift by J. Brozek. The translation of the Polish reference states: "Armillary Sphere, brass, golden with a clock in the central globe. Gift of Joannis Brosci” (Babicz, 1970). It has been hypothesized that Brozek might have brought this armillary sphere from Italy to Poland via Salzburg where in May of 1620 he was in contact with Christoph Scheiner (1573-1650). Brozek studied Medicine at the University of Padua between 1620 and 1624 where he received his doctorate in Medicine on 11 August 1623 (Franke, 1884).

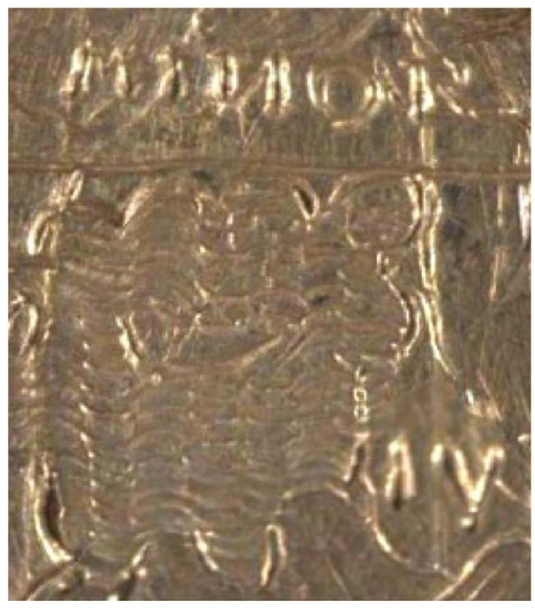

Figure 2. Appears to be a small fishing boat in the Eastern Mediterranean instead of the island of Cyprus. Picture courtesy of the Lazarus Project and the University of Rochester 2020. 
In contrast, with Stevenson who dates the Jagiellonian Globe to 1510 and quotes the Polish researcher T. Estreicher that this object from the beginning of the sixteenth Century belongs to the library in Cracow (Stevenson, 1921).

In the following descriptive paragraph, I have a detailed look at the Jagiellonian Armillary Sphere containing the small terrestrial globe.

The upper surface of the horizon ring is graduated with a numbered scale of 360 degrees, divided every 10, 5 and 1 degrees. Compass directions usually indicated by an arrow on the horizon ring for the North and a cross for the East are absent. The circles in the armillary sphere in gilded bronze are composed of three polar systems. These are the horizontal, the equatorial, and the ecliptic or solar circle. The most massive and farthest from the surface of the globe is the immobile horizontal system, consisting of a ring of the horizontal circle and meridians. The less massive mobile equatorial system, placed closer to the surface of the globe, is based on the ring of the celestial Equator and the first vertical. In addition, in this system there are two tropics, two polar circles and 24 meridians, one in two of which touches the polar circle, and one in four, at the pole. At the crossings of the meridians with the Equator 24 dials are placed with exceptionally interesting Roman capital numerals $(2 \times 12)$ showing the time, to which I will return. The solar system set in motion by the clock mechanism (Taborska, 2020) having the most fragile construction, is placed closest to the surface of the globe. It consists of six circles perpendicular to the ecliptic and crossing the poles of it. On the ecliptic the signs of the zodiac and the longitudinal scale at 30 degrees are engraved. There is also a ring with the calendar divided into days and months, and around the South Pole a dentélé i.e. a serrated circle to which a handle is fixed with a star at the end representing the Sun. This star rotates around the Earth and at the same time shows the time, day, month and position of the Sun above the Earth. As the equatorial system turns, the solar system, thanks to the clock mechanism, advances by 1 degree (Babicz, 1970).

The median ring within which the primary sphere is contained is fitted into a pair of slots in the horizon circle. One face of the meridian ring is finely graduated with a scale of 360 degrees divided to 10 degrees, 5 degrees and 1 degree numbered four times from 10 degrees to 90 degrees.

It is important to have a closer look at the hour ring on the Equator. It has small brass plates containing reversed punched Roman capital numbers with divisions for 24 hours subdivided into twice twelve hours (Figure 3). Rather highly unusual is the matter that the order of the Roman capital numbers is inverted. Thanks to a personal communication from the Italian Clock Expert Dr. Marisa Addomine, it was detected that the aforementioned reversed Roman capital numerals and their inverted order seems to have remained unnoticed in the epigraphic research on this unique astronomical clock.

The Roman capital numerals on the hourly meridians and its sequence are mirrored. It is as if the maker or the person who constructed the layout copied by the Renaissance horologist, most likely of French origin wanted to insure a concave vision of the universe. The foregoing concave vision, a distinct 
Jagiellonian Armillary Sphere 1510: Inverted Roman capital numbering (concave)

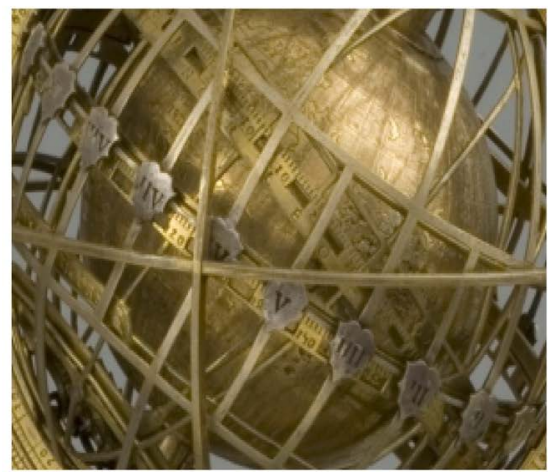

Picture: Public domain 2017
Museum Correr Venice Armillary Sphere (Mid 16th century): Correct Roman capital numbering. Inv. CL. XXIXn 31

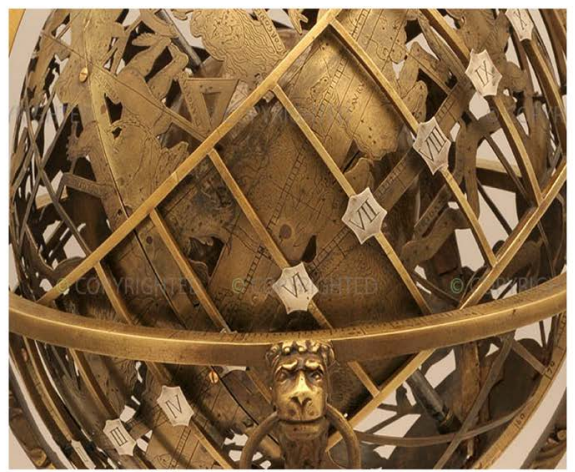

Picture: @ Photo

Archive - Fondazione Musei Civici di Venezia 2020

Figure 3. The inverted Roman numbering on the Jagiellonian versus the correct Roman numbering on the contemporary armillary sphere from the Museum Correr.

iconographic motif is contained in the Jagiellonian Armillary Sphere. This discovery is the result of a personal communication with the expert Dr. Georg Zotti. In the history of scientific instrument making this distinct concave aspect in a Renaissance armillary sphere, to which I shall come back in this article, is extraordinarily unique.

At the North and South pole of the meridian ring an axle to which the primary ring attached is mounted. There are seven rings in the sphere. Two represent the colure while there are five parallel rings, for the polar circles, the tropics and the equator perpendicular to the colures. The equatorial ring is wider than the others and is engraved with a scale of 360 degrees, divided every 10, 5 and 1 degree numbered from 10 to 360 every 10 degrees. The numbers reflect a late Gothic and early Renaissance style. A graduated band representing the ecliptic is tangential to the tropics. This band is graduated and divided into twelve equal parts of 30 degrees each containing the names of the 12 months in Roman capital letters and then every 5 and 1 degree (Babicz, 1970;Kugel, 2002). The equatorial ring is divided on a scale from $0^{\circ}$ to $360^{\circ}$ and the ecliptic according to the twelve zodiac signs, from $0^{\circ}$ to $30^{\circ}$ each, corresponding to the Julian calendar (45 BCE-1582) on the inside of the ring.

The third ring, together with a clock pointer in the form of a small Sun that is attached to the pen, is movable. It revolves around the globe, which is located in its center, showing the hours on the labels as well as the day and month and the position of the Sun in relation to Earth.

On top of the armillary sphere there is a highly unusual motif that is one distinguishing feature of the Jagiellonian instrument. It is called a throne, a suspension bracket seemingly inspired by thrones with two decorative holes of the $12^{\text {th }}$ century brass astrolabes from Bagdad (Kanas, 2019), with a hinge so the instru- 
ment can be hung upright (Pingree, 2009).

In some early Islamic astrolabes, the throne verse (āyat al-kursī) from the Qur'ān (Surah 2:255) is engraved on the suspension bracket, which reads: "His throne extends over the heavens and the Earth." Therefore, the suspension bracket, usually of a triangular shape, came to be called Kursī (Throne) in Arabic language (Sarma, 2019) to be followed by Western texts. In analogy, the heavy plate of the astrolabe which carries a series of circular discs, just as the mother carries the child in her womb, is called mom in Arabic and "mater" in Latin and in English. In Sanskrit astrolabes, the writers refer to the throne as the crown, which is generally high and often solid, with lobed profiles, and occasionally with the two decorative holes as in the early mid-eastern astrolabes. In some cases, the front side of the solid crown is decorated with a floral design in bas relief (Sarma, 2019). Kursī can also mean the stand supporting the horizon ring for a celestial globe (Savage-Smith, 1985). A highly uncommon motif and distinguishing feature of the image of the throne of the Jagiellonian are the single looped sashes. The style of these elements of the image of this throne, in an adapted triangular shape on the Jagiellonian, reminds us at first of the reversed top of an Ionic pillar. In addition, the small metal plates on which the Roman numerals are visible are typical for Northern Italian Renaissance.

Through the polar axis of the globe a round spindle is mounted, which is tilted at ca. 25 degrees, so that the round spindle attaches the primary sphere at the points, so the Arctic and Antarctic circles touch the solstitial colure. On the inside of the globe there is a small clock made of copper. The early Renaissance original of this clock mechanism has not been preserved. The current one dates from the 18th Century and has been revised several times. It can be wound-up through a keyhole in the lower part. This clock makes the globe turn around an axle (Babicz, 1970).

At the center of the sphere and one of the reasons this globe has drawn the attention of numerous researchers in North and South America and Australia alike, there is a uniquely engraved terrestrial globe representing the Earth and showing for the first time the name of America on an extant globe from early Renaissance. In what follows, I present a comparative analysis of the toponyms on the Jagiellonian followed by a look at the origin of "AMERICA NOVITER REPERTA" in Roman capital letters on its surface.

\section{Comparative Analysis of the Toponyms on the Jagiellonian Globe}

In Appendix A of this article, a comprehensive table of every toponym visible on the Jagiellonian compared with the Lenox and the da Vinci Globe is presented. This appendix is based on primary sources.

What is quite striking when investigating the Jagiellonian Globe is that it has a similar nomenclature (a total of 55 names and abbreviations and 49 numbers) compared with the Lenox and the da Vinci Globe, the foregoing being the prototype for the Lenox. 
However, there are also some significant differences, such as a high frequency (47\%) of spelling distortions, also called spelling mistakes and incomplete variants (Missinne, 2015).

The Lenox (as with the da Vinci Globe) has a total nomenclature of 74 words on a surface of 17.59 square centimeters or $0.238 \mathrm{~cm}^{2} /$ letter. The clockmaker of the Jagiellonian seems to have been forced to leave out $1 / 4^{\text {th }}$ of the toponyms but still reaches a nomenclature of 55 names/abbreviations on a surface of 11.54 square centimeters or $0.209 \mathrm{~cm}^{2} /$ letter.

In other words, although the horologist miniaturized the world globe and thereby only has $2 / 3^{\text {rd }}$ of the 3 -dimensional surface of his elderly sibling, the Lenox, only $12 \%$ less space is comparatively filled with nomenclature. In addition, the clockmaker compressed the cartographic area thereby simplifying certain details.

In contrast to the Lenox, the anonymous horologist adds names for oceans. Furthermore, he adds meridians and parallels. In addition, he is creative in filling out blank spaces, including unknown islands, usually called horror vacui, one of which is rather significant and which I address at a later stage in this article.

A comparative analysis of the enlarged scan of the Jagiellonian Globe was allowed courtesy of the Lazarus project and thankfully provided by Professor Dr. Gregory Heyworth, Director of the Multispectral Imaging Project of the University of Rochester. This detailed comparison with the Lenox and the da Vinci Globe confirmed that the author of the Jagiellonian Globe had access to the Lenox but not to the da Vinci Globe (Missinne, 2018).

This is evidenced by the fact that certain areas on the da Vinci Globe were not visible due to their gluing on the Equator as can be seen in the unfolded versions in Figure 4, while these areas are clearly recognizable on the Lenox and Jagiellonian. That is notably the case on the Equator North of the so-called tiger leg, the large protruding South East Asian Peninsula, while visible on the area surrounding the mouth of the Amazon River (Missinne, 2018).

Interestingly, based on the comparison of the nomenclature, several orthographic examples in support of the French authorship of the Jagiellonian were found. The engraver used "POL $\Lambda$ RTICVC" instead of "CIRCVLVS ARTICVS" thereby stressing the abbreviation, " $P O L$ " for the French word " $P O L E$ " or the Latin "POLVS." The distinct abbreviation of "POL" seems to indicate that the French horologist may have had access to the engraved woodcut brochure (which uses meridians and parallels) printed in Latin in Strasbourg with the help of Johann Adelphus Muling by J. Grüniger in August of 1509. In that woodcut booklet the word "POLVS" is printed. In addition, "AFFRICA" is spelled with two F's on the small world map contained in that woodcut booklet. Interestingly, the spelling of AFRICA on the Jagiellonian is identical as AFFRICA is also spelled with two F's. The introduction of these mistakes on the Jagiellonian Globe looks like a strong first indication that the clockmaker copied the same spelling errors from that peculiar woodcut map. 


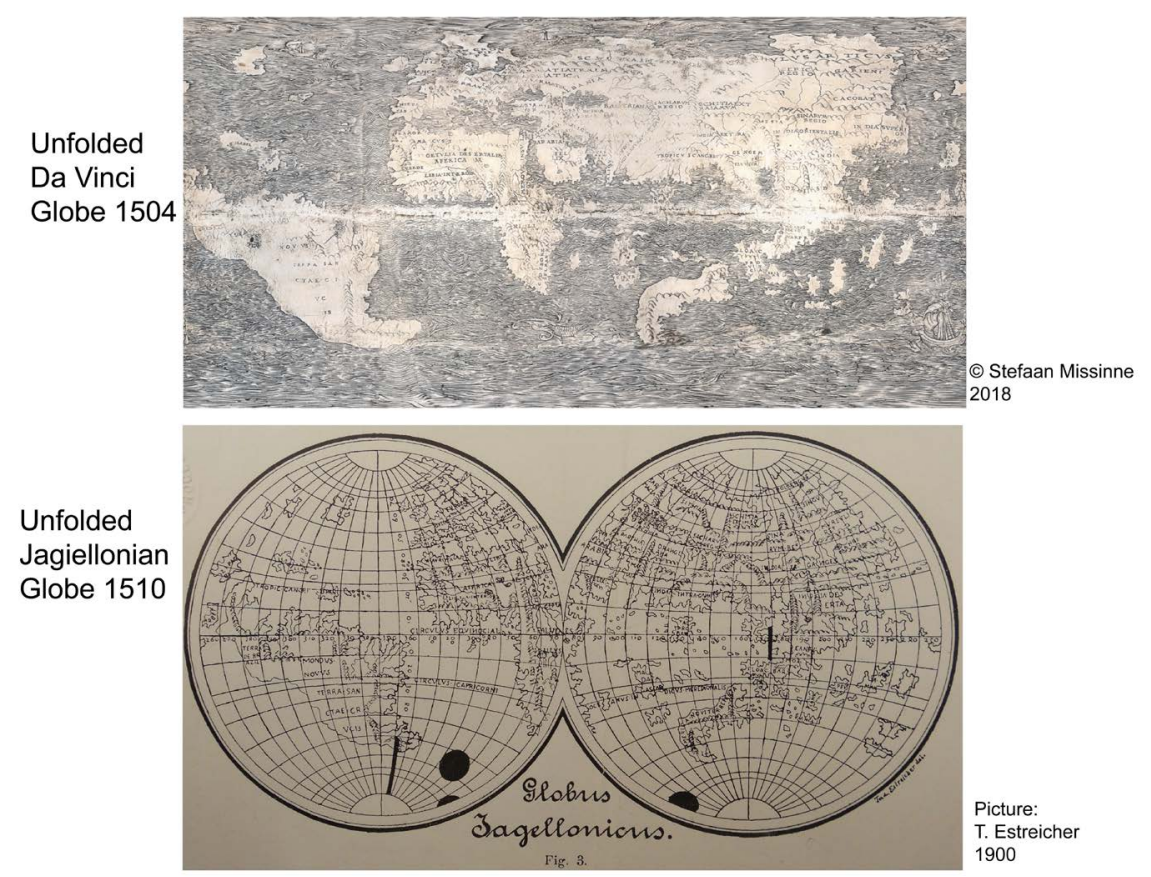

Figure 4. The unfolded da Vinci Globe from 1504 versus the unfolded Jagiellonian Globe from 1510.

Although, the foregoing seems to be rather significant, the clockmaker or maybe a colleague of his does not seem to copy blindly. He makes orthographic adaptations. For example, he changes "LIBIA*INTEROIR" on the Lenox Globe,

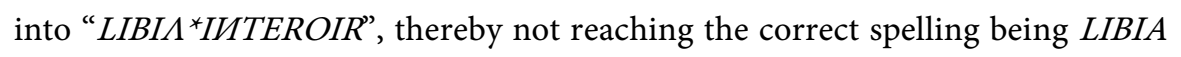
INFERIOR (as on the Germanus Globe gores) (Missinne, 2015).

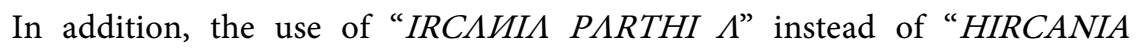

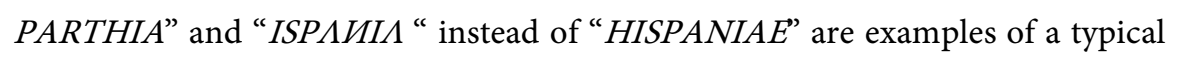
French orthographic omission of the first letter "H", followed by an "I". Finally, the abbreviation of words like "TAPROB $N$ " instead of "TAPROBANA" and the brief word partition "TROPIC", as in the French language "TROPIQUE" instead of "TROPICVS" and the short " $\triangle \mathrm{EGIPT"} \mathrm{instead} \mathrm{of} \mathrm{"EGIPTVS"} \mathrm{not} \mathrm{coin-}$ cidental.

Due to the lack of available space on the small globe, the shortening of the toponyms such as the capital letter "I" for the French IRLANDE, instead of the Latin HIBERNIA adds to the above French origin of the horologist and was certainly a spontaneous necessity.

Hypothetically, the use of abbreviations may also have been caused by the working circumstances while copying directly from an existing armillary sphere, peering through the numerous celestial rings.

It is not unimportant to mention that the name of "GERMANIA", neighbor-

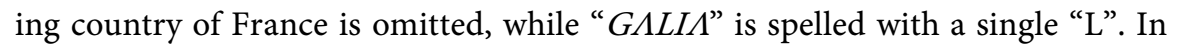
contrast "ASSIA" with two S's as on the Lenox and the mentioning of the " $A S I A$ " for the Asian continent is omitted on the Jagiellonian. T $\Lambda$ RT $\Lambda$ RI $\Lambda$, an abbreviated form of TARTARIA MAGNA, is used instead, which also replaces 
SARMATIA and SARMATIA TRA IMAVM ASIATICA as used on the Lenox (Missinne, 2018).

The horologist or a colleague decides to add a few different toponyms such as for example " $D R \Lambda И G I \Lambda И \Lambda$ ", " $M A N G P$ "," $M N G A$ ", " $C A N F V$ " and "IRCA $И I \Lambda$ $P \Lambda R T H I \Lambda$ " and the above mentioned "I". The word " $A R B E T$ " is engraved on a small unidentified imaginary island on the equator to the West of Latin America as mentioned by Estreicher. The control of that name using the detailed 2020 scan of the Jagiellonian Globe only showed traces of that name due to a strong corrosion of that area. I have not seen any plausible or convincing source for the name of ARBET nor have I encountered any similar name in later globes or maps.

The maker of the Jagiellonian Globe focused on aspects of astronomical precision and measurement, thereby adding 49 numbers to classify latitude and longitude. According to Prof. Dr. Andreas Zajic, these numbers epigraphically reflect the late Gothic early Renaissance style which is concordant with the date of the object. In addition, in $29 \%$ of the cases word breakers or expiring triangles (Dreisporne) are added. According to Dr. Rüdiger Fuchs, in a personal communication, the fewer word breakers are used, the earlier the likely date of the globe instrument. In comparison, in only $4 \%$ of the cases a word breaker is applied on the da Vinci and on the Lenox Globe.

It is not insignificant that the position of Ferro is used for the prime meridian on the Jagiellonian Globe. This prime meridian had been known since antiquity. On the da Vinci and on the Lenox Globe the prime meridian, and all other linear meridians and parallels for that matter, are omitted.

Though most significant for the matter of trading, the highly important port city of Caliqut (CALIQVT) indicated on the da Vinci, Lenox and on the 1507 Germanus Globe world map and described in great detail on the 1516 Carta Marina by Waldseemüller (Van Duzer, 2020) is missing. Furthermore, the name of Cape of Good Hope ( $C D E B O N E S P E R A N Z A$ ) is not engraved either.

This may be due to the fact that it was to be kept secret. The more likely reason may be a certain indifference or that the horologist was not aware of the importance of the mercantile culture of Renaissance Florence. The omission of these specific geographic locations but notably the omission of the name of spice Port of Caliqut seem to be supporting the thesis that he was concentrating on the miniaturization and on the issues pertaining to the internal functioning of the clock.

Toponyms were left out by the French horologist that are clearly evident on the da Vinci and the Lenox Globe, but which are not on the globe gores of Germanus nor on the Jagiellonian Globe include:

“HC SVNT DRACONES, ANFVROIN, ALBANIA, BABVLONIA, BACTRIANA, CIRTENA, VARP R, INDVS, PARTHIA, GENGEM FLVVIVM, SIRIA, SIMARVM SIT( VS), TRALMAVM."

The Jagiellonian Globe offers the terminus ante quem of the construction of the Lenox Globe. This is substantiated by the fact that the Jagiellonian copies the cartography from the Lenox and not from the da Vinci Globe. Even the highly 
distinctive cartographic feature of the unusually short longitudinal distance between the eastern and western coastline of Central Africa is replicated.

The horologist could not have copied the cartography from the da Vinci Globe as in a number of cases the areas on the Equator which are blurred due to the gluing of the two conjoined ostrich eggshells are not visible and could therefore not be copied (Missinne, 2018).

Summarizing one can deduct from the above that the Jagiellonian applied the cartographic knowledge and $3 / 4$ of the toponymy of the Lenox Globe adding a few extras. The Lenox has a richer toponomy and artistic pictorial content. The Lenox did not copy from the Jagiellonian as evidenced by the comparative analysis in Appendix A but vice versa. Now I have a look at the appearance of the name of AMERICA on the Jagiellonian Globe.

\section{The Origin of the Name of America on the Jagiellonian Globe}

The fact that "AMERICA NOVITER REPERTA" (Figure 5), which means "recently discovered America" is engraved indicates that the Jagiellonian Globe was constructed after 24 April1507, the first-ever time the word America was printed namely in the first edition of the Cosmographiae Introductio in St. Dié. The French horologist seems to have been confused about the precise location in the antipodal region of the newly discovered world. As a result, he engraved "AMERICA NOVITER REPERTA" in the wrong place, namely on a large, unnamed cartographic island in the Indian Ocean. This island has a mountain range which is aligned for much of its length along a meridian. In addition, several rivers flow to the East from these mountains into the unnamed Indian Ocean. This is in contrast to the mythical island named DIAB which was separated from South Africa by a channel (Van Duzer, 2007). King defined the bifocal location of the name of America and cites the famous contemporary German Cartographer Martin Waldseemüller (King, 2014).

In his chapter on climates in the Cosmographiae Introductio from 1507, Waldseemüller writes: "Atq[z] in sexto climate Antarcticù versus \& pars extrema Africae nuper reperta \& Zamzibar Iauva minor \& Seula insule \& quarta orbis pars (quam quia Americus inveuit Amerigen quasi Americi terr $[=a]$ siue Amer$i c[=a]$ nuncupare licet) sitae sunt."

In English: "In the sixth climate toward the Antarctic there are situated the farthest part of Africa, recently discovered, the islands Zanzibar, the lesser Java, and Seula, and the fourth part of the Earth, which, because Amerigo discovered it, we may call Amerige, the land of Amerigo, so to speak, or America (Stevenson, 1921)."

The possibility cannot be excluded that the horologist had access to the Cosmographiae Introductio of Martin Waldseemüller, but no evidence for such substantiation be it cartographic, bibliographical, orthographic or toponymic could be found. Based on the evidence that the horologist, in contrast to the Lenox 
Comparison: Anonymous large island in the Southern Indian Ocean on the da Vinci/Lenox Globe versus the named large island on the Jagiellonian

Da Vinci Globe 1504

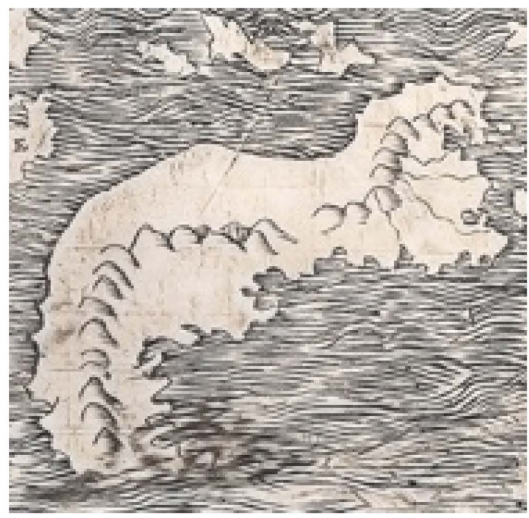

(c) Stefaan Missinne 2018
Lenox Globe 1504

Jagiellonian Globe 1510

\section{"AMERICA NOVITER REPERTA"}

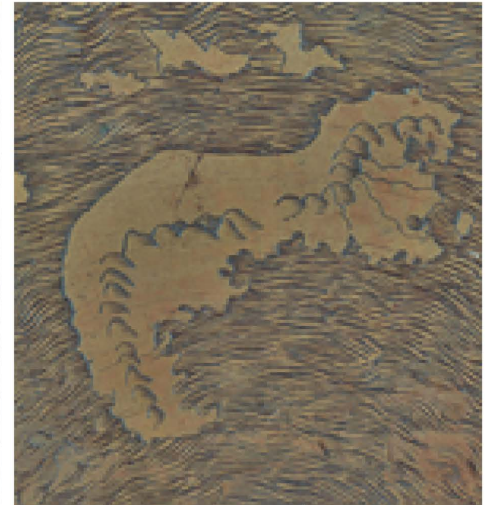

Picture courtesy of the New York Public Library Rare Book Division, Astor, Lenox and Tilden Foundations 2018

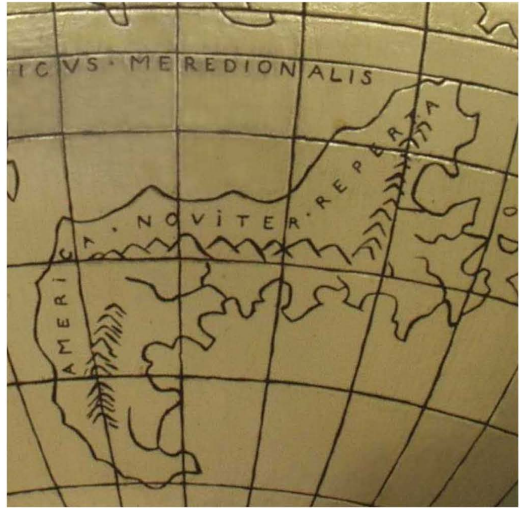

Picture courtesy of the Jagellonian University Museum - Grzegorz Zygier 2018

(a)

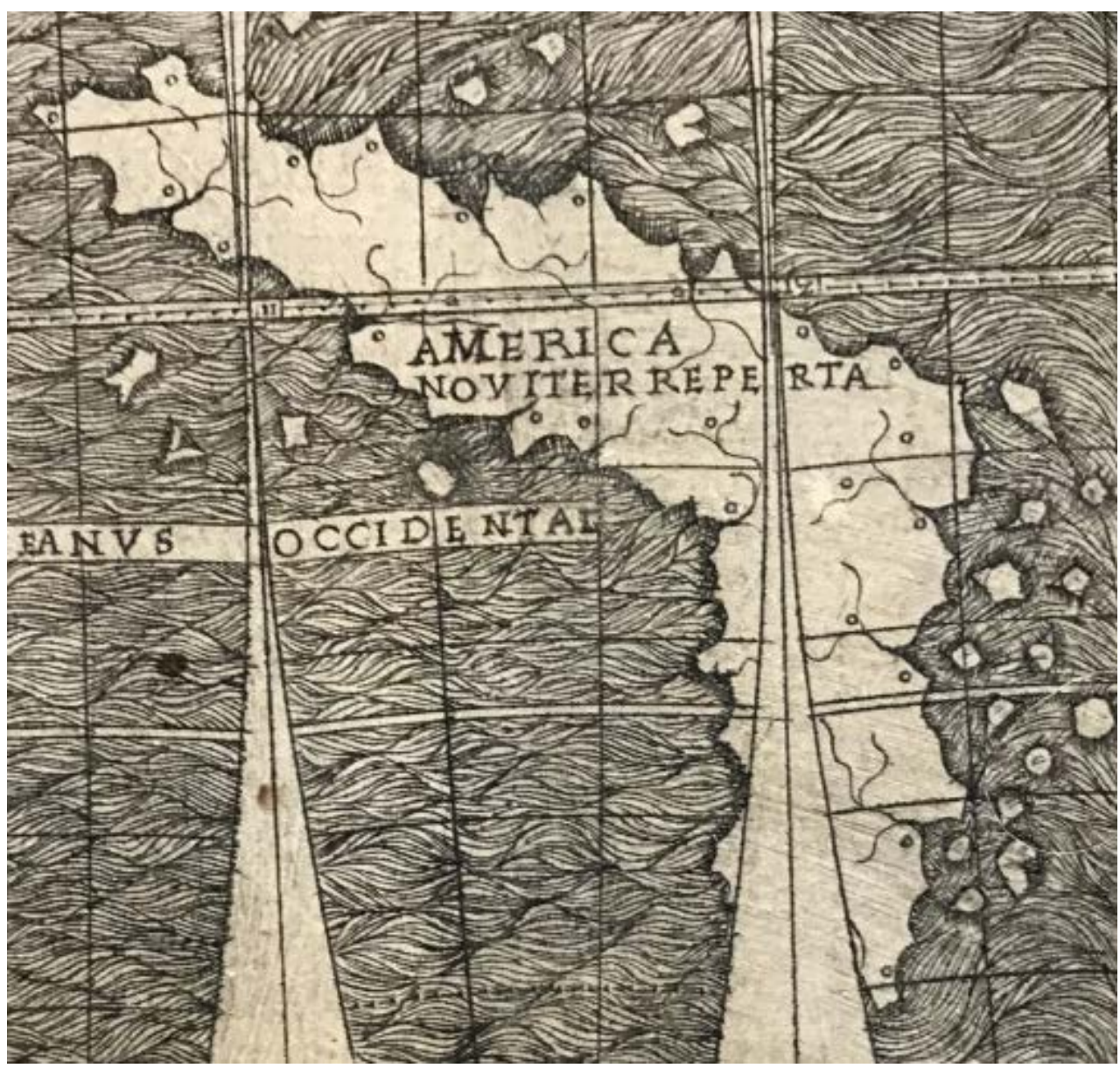

(b) 


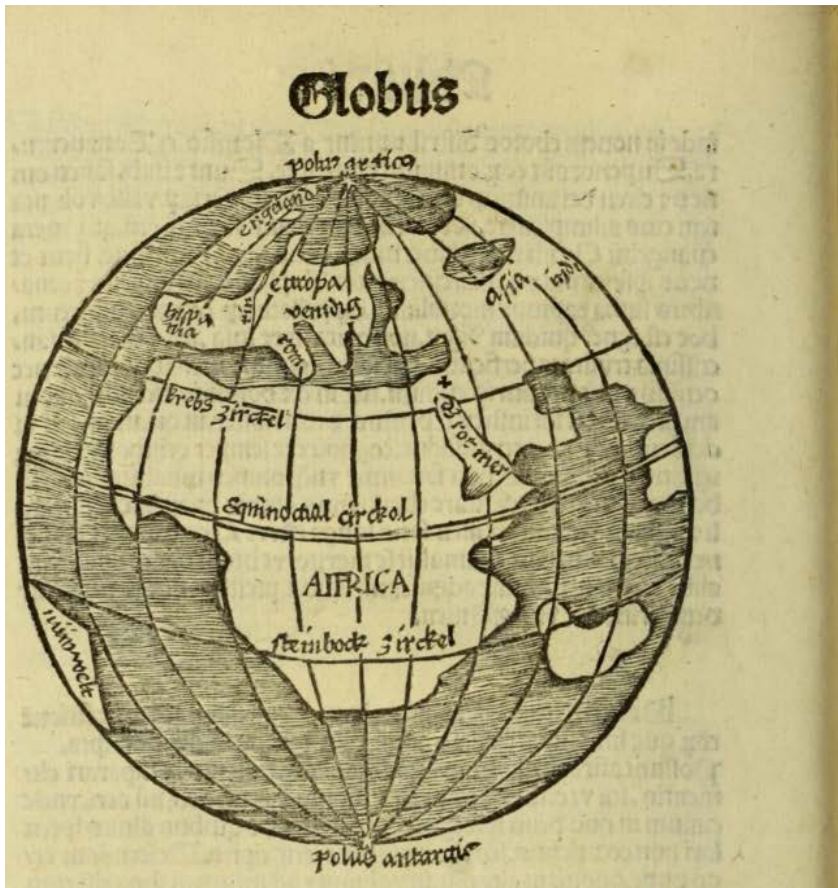

\section{D)untioi}

onctoribus comparatur cozpozi bumano,quoniä in ea omnia repe runtur. que funt in cozpoze noftro. Printi caro eft ipfa terra, fan, ruis aqua ofla funt lapides, vene nontes, caput ipfum eft ozicns gure af

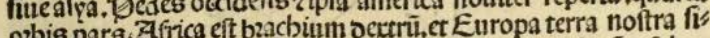

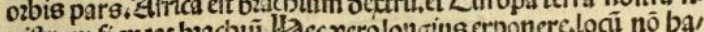
niltrum figurar bzacbuil. Bec verolongins ectonere,

Tota aute terra cóparatur globo fue pomo.vt ad oculī vides non q neceflario zad amuff m rotunda effe ocbeat quaficirculus fed quoniam buic ficuremaxime omniû fimilacur,quoniä aer ipy fe repler foraminaz terre concautratcs, que non refpondent fuper' fe replet fozamina zterte concautra loquar, replet aer quare in gene

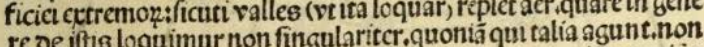
pbilofophifed pbilofopbitar nuthcupandi funt,quoniä terra ipa pbin in do pender aere,nulli innica nifi feipfa,nullo item nifi folo ita in nudo pendet aere,nulitinnica nil bilipfa.nt puncus in circulo verbo oei firmatain medio ontniü ftabilita, vt punctus in ciraulo Etquantũ eft abbincadufä cclum.tantí za quocilo locó globü tocî ozban eins:fno modo o.cendi, Etad quencing locen globus ipfumpofueris idem eft.quare notare poteris (cafacie) vndig ter ram inbabitarivel ab bontmibus vel butis infia fupaza latere nisul noficite crederc,pedes coz elle noftris oppofitis, quonias

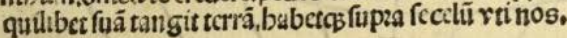

\section{Capis,oe quinq: circulis maios}

(c)

Figure 5. (a) Large island in the Southern Indian Ocean on the da Vinci/Lenox Globe versus "america novite rreperta" on the same island on the Jagiellonian; (b) World globe gore map by Germanus dating from 1507-1508 at the New York Public Library. Picture made by Missinne (2018) courtesy of the Rare Book Division at the New York Public Library; (c) The Latin printed Globus Mundi dating from 1509 with the printed reference to "america noviter reperta", 4th line upper right corner. Notice the spelling of AFFRICA on the map to the left. Public Domain.

and the da Vinci Globe, uses cartographic precision instruments such as meridians and parallels, I consider this so-called bifocal argument based on Waldseemüller's world map to be merely coincidental.

It is worthwhile to have a closer look at the erroneous location of the wording containing the name of AMERICA on the Jagiellonian Globe.

Since the name "America" is missing from da Vinci and the Lenox Globe, although there are already three toponyms on the Latin American Landmass of the Lenox, the clockmaker may have chosen a left-over empty space that is even more western for him.

Due to the lack of space on the small globe this large unknown, anonymous and "empty" island seems to have come in handy for him during the continuous mental production work he updated and added the phrasing in Latin "recently discovered America".

To substantiate the above, the unknown island could potentially be evidence that the horologist had access to a small printed world map, maybe even the very rare small copper engraving depicting the world by D.N. Germanus dating from approx.1507-1508 as a template.

Indeed, at first sight a detailed stemmatic comparison of the toponyms of the da Vinci Globe/Lenox, the Jagiellonian Globe and the Germanus copper engraving globe map, with the phrasing "America noviter reperta", would lead me 
to believe that the French copyist of the Lenox and maker of the Jagiellonian Globe had access to this copper-engraved globe map by Germanus, printed in France at the end of 1507. The singular phrase "America noviter reperta" is individually engraved on a lonely "island" on the Germanus Globe gore map (Figure $5(\mathrm{~b})$ ).

The foregoing omitted or replaced the words MUNDUS NOVUS, TERRA SANCTAE CRUCIS and TERRA DE BRAZIL by the new name AMERICA.

The examples that are very similar in spelling on both the globe gores of Germanus and the Jagiellonian Globe and therefore offer some thought for a potential but nevertheless insufficient evidence of a common source but which do not appear on the Lenox and the da Vinci globe, are:

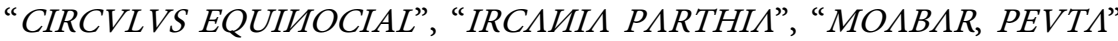
and "CIRCVLVS CAPRICORNP" (Missinne, 2015, and Appendix A).

In contrast, it appears that the cartographic differences between the Jagiellonian and the Germanus Globe gore world map are too great in number to support the hypothesis that the clockmaker used the Germanus gores for the cartography of his globe.

In the course of this research, it is significant to mention that until 2015, the above-mentioned globe gores were erroneously dated to later than 1517 and mistakenly attributed to Louis Boulengier. These copper engraved gores at the New York Public Library Inv. Nr. KB+++1517 are designed for a globe of approximately $11 \mathrm{~cm}$ in diameter. In fact, they are about ten years older than the date given in the literature, and they are, therefore the oldest surviving American cartographic birth certificate (Missinne, 2015) preceding the oldest extant reprint of the large 1507 Waldseemüller World map at the Library of Congress dating from after 1515 (Hessler, Karnes,\&Wanser, 2008;Hessler\& Van Duzer, 2012; Metcalf, 2020).

As a potential candidate for the source for the "AMERICA NOVITER REPERTA", this leaves us with the above-mentioned printed woodcut of the "Globus Mundi: Declaratio sive descriptio mundi et totius orbis" by Johannes Adelphus printed in Strasbourg and dating from 1509.

The uninhabited large island in the Indian Ocean is lacking on the Germanus gores. This in addition to the above-mentioned cartographic difference offers key evidence that the horologist was aware of the naming of America but not about its precise cartographic location.

On the small-printed woodcut world map in the Latin edition of the GLOBUS MUNDI booklet by Adelphus, the Latin phrase "america noviter reperta" is clearly printed in the text of the small booklet and the words nüw welt meaning new world on a large triangle "island" in the South Western Atlantic Ocean are clearly visible.

The above textual reference but the lack of cartographic template may have led to this cartographic confusion for the horologist resulting in the first ever engraving of the name of AMERICA being situated in the wrong place. 
One should not forget that for many the location of the new world was unsure. In addition, in many cases cartographers and engravers alike were confused between expeditions and the use of cartographic doublets, for example, of islands such as of Taprobana. Therefore, a substantial unlabeled island came in handy. There wasn't any need of verisimilitude on behalf of the original, but it stands in contrast to the clockmaker's achievement and updating. This large unnamed diagonally aligned island from Southwest to Northeast is not to be confused with Menuthias (Ptolemy's Geography 4.8) as mentioned in the volume with the title "The Periplus of the Erythraean Sea", which refers to the largest and most populated island of the Zanzibar archipelago, in Tanzania.

On a Ptolemaic land bridge between Africa and Asia, as on the ca. 1480 circular copper engraved Woldan Map in the collection of the Austrian National Academy of Sciences, printed on a world map of Gregor Reisch in the woodcut publication dating from 1503 in Basel with the title Margaretha Filosophica (Van Duzer, 2020), it states in Latin translated here into English: "Here is not land but sea, in which there are islands of remarkable size unknown to Ptolemy." (Van Duzer, 2020). The location of the phrase and its content "islands of remarkable size" are in the South Indian Ocean, where the horologist put "AMERICA NOVITER REPERTA."

It suffices to say that this early modern phrase "unknown to Ptolemy" referred to the newly discovered world that, until Vespucci's Mundus Novus dating from 1503, was believed to have been an island, something which may have complicated the matter for the horologist.

As mentioned, it is important to stress that the Latin phrase "AMERICA NOVITER REPERTA" was first used in 1507 on the copper engraved globe gore world map layout, with such content ascribed to Donnus Nicolaus Germanus (Missinne 2015).

Only two years later this Latin sentence was included as a woodcut in the "Globus Mundi: declaratio sive descriptio mundi et totius orbis" printed by Grüninger in Strasbourg (Missinne, 2015). So, logically the French horologist who copied from the Lenox at first engraves the three cartographic words on the Jagiellonian Globe (Figure 6): "TERRA DE BRASIL, MVNDVS NOVVS and TERRA SANCTAE CRVCIS", the latter two words conjoined, from the Lenox and subsequently, he adds, possibly after having received the latest printed "cartographical" news from Strasbourg dating from August 1509 "AMERICA NOVITER REPERTA". In what follows I review certain characteristic aspects of epigraphy and orthography.

\section{Aspects of Epigraphy and Orthography}

In numerous cases, the horologist uses retrograde N's which mostly appear on the exaggerated extension of the Eurasian landmass, bearing most of the topo-

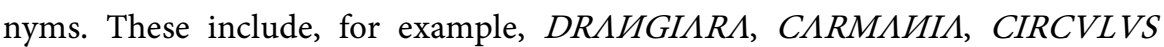
EQUIИOСIAL, IИDIA IИTRA GAИGES, INDIA EX^ GAИGES and IUDIA 
Comparison: America on the da Vinci/Lenox Globe versus the Jagiellonian

Da Vinci Globe 1504

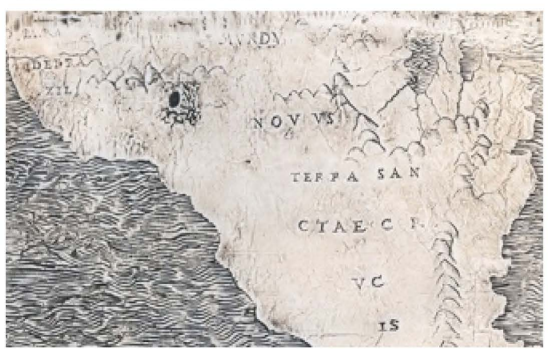

(c) Stefaan Missinne 2018
Lenox Globe 1504

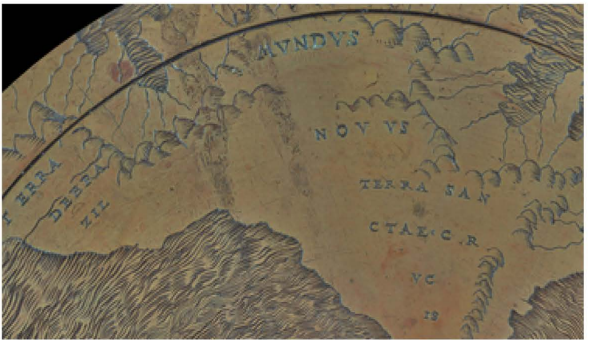

Picture courtesy NYPL Rare

Book Division, Astor, Lenox

and Tilden Foundations

Jagiellonian

Globe 1510

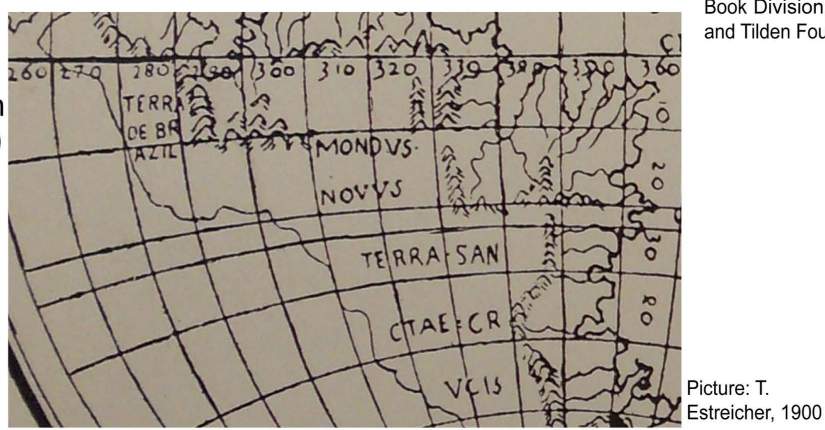

Figure 6. Comparison America on the da Vinci/Lenox Globe 1504 versus the Jagiellonian Globe from 1510.

DESERTA. None of these retrograde N's are used on the Lenox, da Vinci nor on the Germanus Globe gores (Missinne, 2015).

During the early modern period, the use of retrograde N's in combination with normal N's is not unusual. But according to Dr. Andreas Zaijc, in a personal communication, the retrograde $\mathrm{N}$ in combination with the use of the reversed A without a horizontal bar, or a $\mathrm{V}$ upside-down is highly unusual if not completely unknown in epigraphy.

This upside-down $\mathrm{V}$ is the case for example in: ISABELLA, EUROPA,

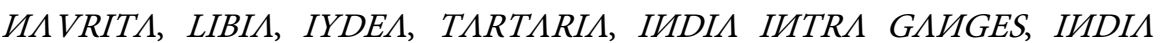
DESERTA, etc.

None of these upside-down V's is used on the Lenox, da Vinci nor on the

Germanus Globe gores.

A capital letter A without a bar, which appears like a mirrored letter V, a letter $\Lambda$, could indicate that these Roman capital letters were punched instead of being engraved. Notably as the size of the capital letters does not seem to vary. But the control of the primary data presented by the highly detailed scan of the Jagiellonian Globe did not confirm the use of punches for the upside-down letter V.

Engraving these capital letters perfect between the imaginary straight lines on a circular object is more than difficult. The ups and downs of engraving of the Roman capital letters are not from a steady hand like Leonardo's on the da Vinci Globe. Furthermore, it can hardly be compared with the perfect calligraphy in the painted text "VIRTVTEM FORMA DECORAT" as can be seen on the back of the painting of Ginevra de' Benci at the National Gallery of Art in Washing- 
ton DC (Zöllner, 2003). In addition, these reversed N's and V's could mean that the horologist perhaps worked in an environment of difficult working circumstances with little or bad light.

Finally, it seems that some words such as for example "POL $\Lambda$ RTICVC" and "P $\Lambda L V D E S$ YILLVIS", were engraved with more spacing and potential corrections. This is in contrast to other examples where spelling errors were corrected without additional spacing, such as those described in great detail by Dr. Harald Drös who analyzed the $16^{\text {th }}$-Century gold and silver globe at the Museum of the Teutonic Order in Vienna. Maybe the horologist, as part of a workshop team, constructed this armillary in order to demonstrate his talent in the hope of securing further orders. The latter could explain why in a initial impression this instrument does not have a large cartouche bearing a makers name nor does it have a dedication to a future sponsor. In contrast a mark of a reversed crescent moon with a capital letter $\mathrm{C}$ engraved on the earlier mentioned serrated circle was discovered near the Southern Pole of the globe (Figure 7).

The fact that the Lenox Globe and its now lost armillary case, analog to the celestial globe, dated 1090 H/AD I679-I680 and believed to be part of now lost armillary sphere by Diya ${ }^{\wedge}$ al-DTn Muhammad of the Lahore workshop (Savage-Smith, 1985), was copied very early on, is rather significant.

One can only guess as to where and how this copying happened, but it suggests that the Lenox Globe, which was made to be the central part of an armillary sphere, served as a template or a copied map of the Lenox Globe as a template from Florence as a center of map production (Rombai, 2003) sometime after 1504, but prior to 1510 .

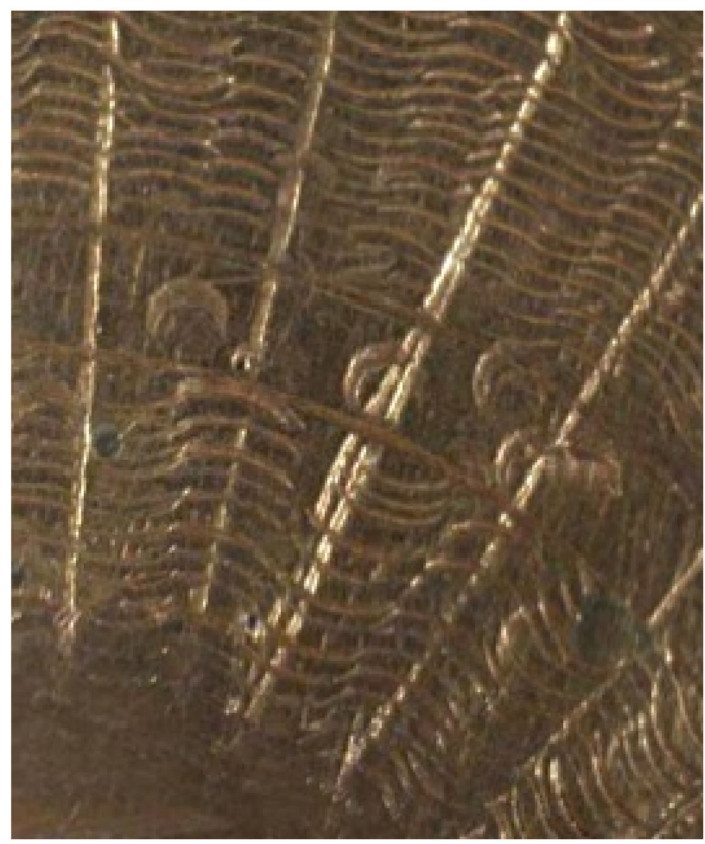

Figure 7. Reversed crescent Moon with a Roman capital letter C. Picture courtesy of the Lazarus Project \& University of Rochester 2020. 


\section{Indirect Evidence of the Hand of Leonardo Da Vinci in the Jagiellonian Armillary Sphere}

As early as 1480, Leonardo made a rather famous drawing (Figure 8) where he is seen sitting observing a standing Ptolemaic armillary sphere from a spectrograph, a perspective window for projecting accurate views of three-dimensional objects. This drawing offers the first pictorial instance of this type of astronomical instrument being in the possession of or used by Leonardo (Kulski, 2019).

His choice of this type of instrument attests for the first time to Leonardo's interest in astronomy and the conceptualization of the universe. During a personal visit to the studiolo in the Urbino castle in 2014 where Leonardo worked, wood inlays were seen which show a hanging astrolabe and an armillary sphere like the Jagiellonian one (Gamba, 2010).

Leonardo da Vinci states that "practice should always be based upon a sound knowledge of theory, of which perspective-wherein is found the glory not only of mathematical but also of physical science-is the guide and gateway" (Winternitz, 1942). In 1504, Leonardo writes "My globe, which Giovanni Benci has".

There are a number of rather peculiar aspects contained in the Jagiellonian Armillary Sphere separated from its $19^{\text {th }}$ Century slim and profiled column with a three-legged foot, which offer evidence of the copying of the now lost Lenox Armillary Sphere, most likely without a stand, containing the Lenox Globe (Missinne, 2018).

The most striking of these aspects are stylistic elements which until now seem to have been overlooked.

The first, and maybe most visible, are the unusual looking Roman capital numerals contained in the small, blackened plaques on the outside of the hour

The Jagiellonian Armillary Sphere

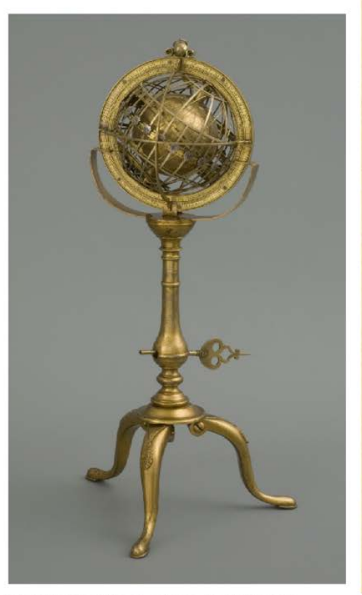

Picture Courtesy of the Jagiellonian Univ. Museum and G. Zygier 2018

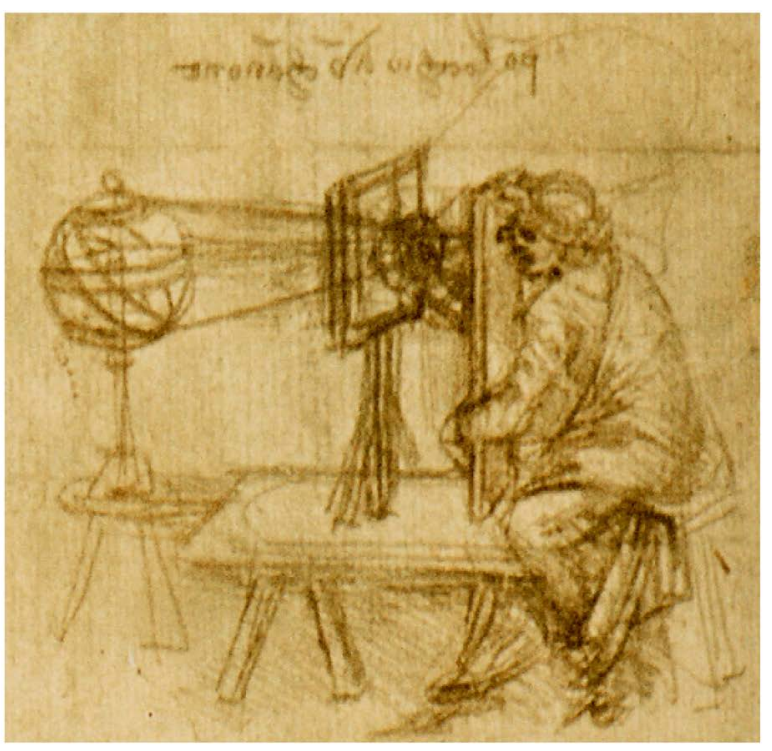

Leonardo da Vinci views an armillary sphere through a spectograph. Notice the throne. Codex Atlanticus page 5 recto 1480.

Figure 8. Leonardo da Vinci views an armillary sphere through a spectrograph. Next to it, a picture of the Jagiellonian Armillary Sphere. 
band of the instrument. Not only are the numbers reversed, but the sequence from left to right from X - XI - IIIV - IIV - IV - V - IIII - III - II - I is reversed. This retrograde form is of some consequence, as this iconographic motif is not merely coincidental but the consequence of deliberation. No other extant armillary sphere could be found where this is the case. Neither T. Estreicher (Estreicher, 1900) nor M. Ch. Guillaume noticed this aspect (Guillaume, 1892). The designer of the object mirrored the capital letters and the sequence on purpose.

In the Greek tradition, the constellation figures of the celestial bodies are conceived as facing the Earth from the concave vault of the starry sky (Dekker \&van der Krogt, 1993). Here, in contrast, the designer of the layout of the Jagiellonian made a different and highly significant choice. No longer do the Greek gods look upon the Earth. In contrast, the concaveness of the Jagiellonian is based on the philosophy for which Vitruvius is well known. Leonardo used this philosophy for his famous and fascinating drawing of a man standing in a sphere so that the Earth resembles man (Wittkower, 1964).These mirrored numbers become correct when man imagines standing on the small globe and looks upward to the sky. Also, the sequence attains its correct form and order. The discerning design is a characteristic of Leonardo (Kemp, 2006).

Later armillary spheres are put on a cast brass figure of Atlas holding the celestial sphere reflecting the above philosophy, which also inspired Italian masons in their inclusion of this decorative element on the outside of the Milan Cathedral. A comparison with the $16^{\text {th }}$ Century armillary sphere Inv. Number CL XXIX 31 at the Museum Correr in Venice shows Roman capital letters in their correct form and a correct order I - II - III - IV - V - VI - VII - VIII - IX - X.

Leonardo is known to have mirrored his writing. There are neither Italian nor French nor German horologists, clockmakers, goldsmiths or cartographers known to have applied this technique. Therefore, the maker of this instrument must have copied it from the now lost armillary sphere containing the Lenox Globe probably holding at its inside a now lost clock. It is in this discourse that in Codex Madrid I, page 11 verso drawings by Leonardo on elements of clockwork and a moon phase indicator are shown. In addition, Leonardo designs a detailed planet mover, possibly even the idea of the Ptolemaic eccentric, for astronomical clocks in Codex Madrid I, page 10 verso (Lohrmann \& Kreft, 2018).

As the Lenox Globe is a cast of the da Vinci Globe, it, therefore, seems logical to support the hypothetical statement that the Jagiellonian instrument is a contemporary copy of an instrument Leonardo created.

In order to substantiate the above, I analyze stylistic, artistic decorative aspects and visual motifs.

\section{Stylistic, Artistic Decorative Aspects and Visual Motifs}

There are a number of cases where indirect evidence is provided by extant bibliographical sources of contemporaries, including lost drawings and paintings by Leonardo. One such example consists in the lost drawings of Leonardo on com- 
parative anatomy (Laurenza, 2006). Based on this idea of indirect evidence, I analyze the stylistic, artistic decorative aspects contained in the visual motifs of the Jagiellonian.

At first sight, it seems that the visual style of the throne is Ionic, but the artist made several additional choices to produce the final artistic appearance of this object. In the following formal visual analysis, I have a careful look at the composition, viewpoint, scale and the use of format. On top of the astronomical object, there is a sphaira, that is, an orb as an attribute surrounded by two upper mirrored volutes as part of a knot symbolism on top of the world axis. The orb is without a surmounted cross comparative to the Santucci armillary sphere dating from 1593 at the Galileo Museum in Florence. The omission of the globus cruciger is not coincidental but deliberate. It is a secular entity and an attribute of the learned man (Dekker, 2000). It is a scientific object where any kind of religious influence is omitted. Leonardo was known to be a non-religious person.

The throne in the form of a characteristic Renaissance element may be a stylistically simplified variant of a Caduceus or a hidden motive (Glori, 2020). The traditional snakes in this throne are simplified to small rings. It is therefore perhaps the symbol of commerce in association with Hermes and the staff of Hermes, a commercial code or term of commerce stressing the optimal interaction of complementary components. The foregoing may offer some evidence that the unique design of this astronomical instrument is not coincidental but refers to world trade in view of the discovery of the New World (Missinne \& Verhoeven, 2019). Most certainly, the foregoing is not a form of seeing shapes better known as Pareidolia or a form of seeing connections known as Apophenia. It is known that Leonardo was highly prolific in terms of puzzles and riddles (Marinoni, 1954). These types of volutes seem to share a characteristic in the mirrored volutes on the side of the small central marble table in Leonardo's youthful oil painting with his master Andrea del Verrocchio of the Annunciation dating from 1472-1475 in the Gallery of the Uffizi in Florence (Caglioti \& De Marchi, 2019). But, as it concerns a scientific instrument and not a painting, it is important to underline that Leonardo surely not only attempted to make something look proportionally good and functional but stressed an underlying significance, scientific foundation, underpinned the layer of the visual impression and part of a specific Decorum (Ames-Lewis \& Bednarek, 1992). In this case, I believe it is based on kinematics and the leonardian fluid mechanics of water (Figure 9).

The preparatory design of the two proportional volutes, with an eye at their center as part of this unique type of throne, is depicted by Leonardo in his Codex Atlanticus page 550 verso dating from ca. 1508. Leonardo adds the words: “due triangoli rettilinei e un' piramide orbiculare, fra due parallele" meaning two rectilinear triangles and one orbicular pyramid, between two parallels. This phrase refers to triangles sheared into spirals. A drawing, which according to Enzo Macagno with some variants, is found in several places in Leonardo's notebooks 


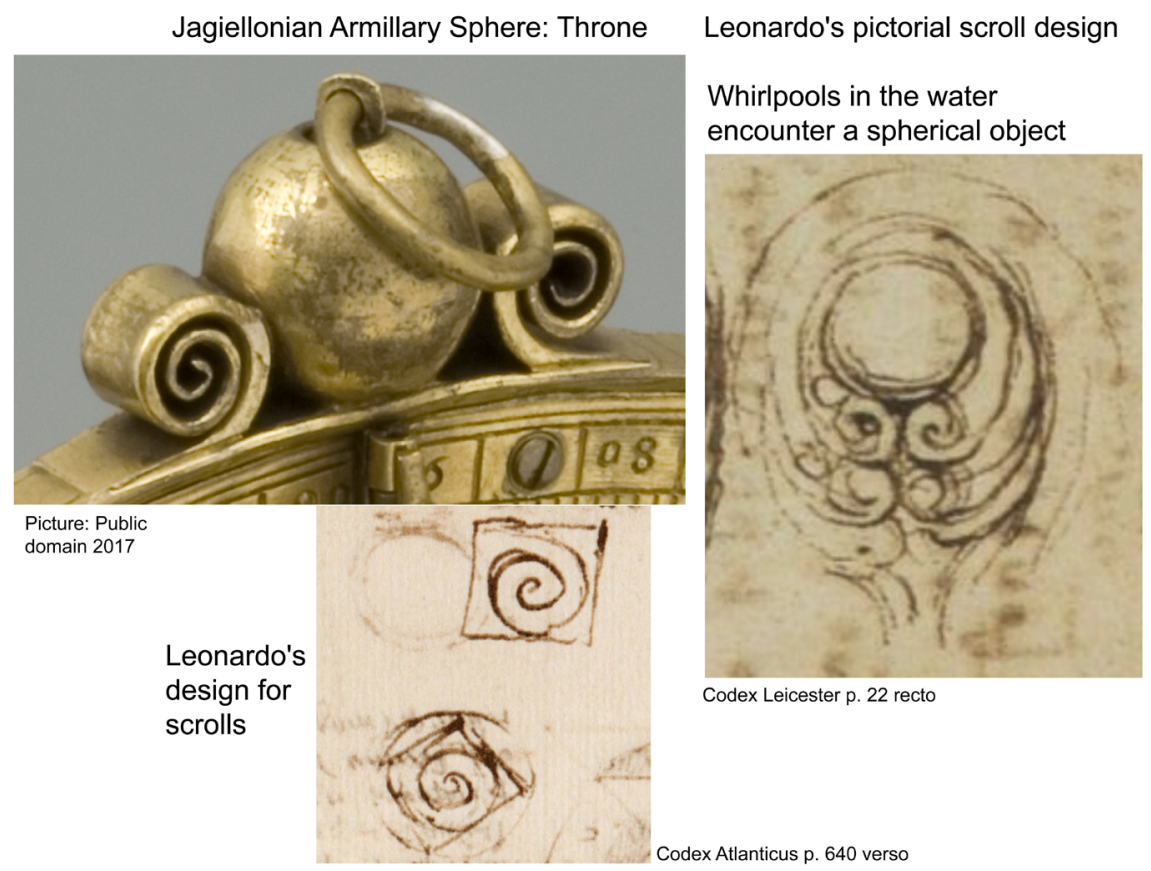

Figure 9. Leonardo's pictorial scroll design versus the throne of the Jagiellonian Armillary Sphere.

(Macagno, 2002). Leonardo is known to transfer his ideas from one codex to another, complicating the matter of the inventory and the sequence of the codices (Bambach, 2003).

The above-mentioned drawing and the one in Codex Atlanticus page 640 verso are both geometrically and kinematically highly significant. Kinematics of the circular shear: Wetting the Earth all around in "Gieometria-DelMoto" in Codex Atlanticus page 692 recto (Macagno, 2002). Unmistakably, Leonardo draws this world-like cylindrical object in double current using scrolls in Codex Leicester page 22 recto (Galluzzi, 2018).

The two reversed proportional circles are miniature geometrical configurations and have the geometric and iconographic content of motion, impetus and force (Fehrenbach, 2002). Leonardo writes in Codex Atlanticus, page 155 verso: "Speak first of the movement then of the weight because it is produced by the movement, then of the force which proceeds from the weight and the movement, then of the percussion which springs from the weight of the movement and often the force (Zöllner, 2010)".

The bi-circular scroll motif is a detail Leonardo not only used in geometry. Leonardo applies this drawing in a lead point reworked with pen and brown ink drawing called: Figure Studies, including a mermaid on top of an Ionic Pillar, and Decorative Elements dating from ca 1480-1481, Inv. 660 at the Museum Bonnat-Helleu (Frank \& Delieuvin, 2019). This is only one example of the iconographic use of a mermaid prior 1492. Sirens, mermaids or maidens in the ocean are depicted on the so-called Columbus map (Ge AA. 562 Rés.) dating from c. 1492 and are the source for the so-called siren islands (Van Duzer, 2007). 
The scroll motif is even depicted in a detail of the drawing RL19116 showing the flow visualization of blood in aortic valve vortices in the left heart chamber (Wells, 2013).

The Jagiellonian Ptolemaic type of an armillary sphere is an ancient Aristotelian model of the moving universal celestial sphere, centered on the Earth and the two circles portray the Earth's spin and the orbiting planets in the cosmos. This type of armillary sphere was created for didactical purposes (Vogel, 1996) in order to better understand the three-dimensional geometry of the universe (Dekker, 2000).

The armillary sphere is in its nature primarily a didactic device and not a measuring tool especially because by arranging the various imaginary circles in the heavens such as the celestial Equator, the ecliptic and others as physical entities, the observer can grasp the purpose and function of these imaginary circles (Sarma, 2019).

Vasari writes about Leonardo as a Geometrician: "And he practiced not one branch of art only, but all those in which drawing played a part; and having an intellect so divine and marvelous that he was also an excellent geometrician, he not only worked in sculpture (Vasari, 1965; Galluzzi, 2006).

The didactic scheme of the armillary sphere made for demonstrative purposes. The famous water-flowing curls are a typical signature of Leonardo (Isaacson, 2017). For Leonardo, art goes far beyond the mimesis of natural forms. There are numerous examples of Leonardo's love for twisting forms (Clark \& Kemp, 2015).

Leonardo writes in Manuscript F, page 27 verso "da mettere esa piramide e non il cube per la terra" which means: "Therefore I will put this pyramid (triangle) and not the cube (quadrat) on the Earth."

The triangular composition of Leonardo (Kemp, 1977; Kemp, 2006) reflected in the throne is another trademark of Leonardo.

Thirdly, as mentioned above, the small metal plates resembling a small shield in the form of a teschio or testa di cavallo on which the Roman numerals in masterly capitalis quadrata are visible are typical for the Northern Italian Renaissance. It is a very ancient shield. For some it is even the first shield ever used in Italy, which usually has seven corners: two on the upper side; two on each of the two lateral sides; and one below which forms the tip.

This heraldic detail of the pictorial motif of the saffron or horse head reminds us of the design of the Viola Organista invented by Leonardo. This heraldic type of family shield can also be seen to the right of the armillary sphere in the famous Boticelli painting of the chapel of the Vespucci Family in the Ognissanti Church in Florence (Fairey \& Caradonna, 2010). These small shields differ from the heraldic samite French shields which typically have in their two upper corners two protruding points, thereby supporting the likelihood that the engraver was inspired by a Renaissance artist active in Northern Italy (Ferrari, 2020).

Leonardo is known to have drawn this type of heraldic shield or stemme. His rebus emblem of the Cross of St. Andrew referring to the conquest of the Duchy 
of Milan is kept at the Library of Windsor Castle. The choice of these horse head type of shields forms part of Leonardo's decorum.

The design and use of the different dimensions of the rings from the most filigree near the surface of the Earth to the thicker dimensions on the outside ring not only has a mechanical purpose but is a matter of practicality and also reflects Leonardo's decorum. This was copied by numerous followers such the mechanical spheres attributed to Jacques de la Garde from Blois dating from ca. 1540 and by Pierre de Fobis from Lyon dating from ca. 1540-1550 (Kugel, 2002).

Finally, the above mentioned is substantiated by the published irrefutable physical, pictorial, chemical, cartographic, mathematical, calligraphic, bibliographical, iconographic and narrative evidence described in the research on the da Vinci Globe (Missinne, 2018; Missinne \& Verhoeven, 2019). The identical twin of the da Vinci Globe is the copper cast Lenox Globe (Missinne, 2013).

As the Lenox forms the model for the Jagiellonian Globe, of which no other sample exists, this substantiates, in addition to the above-mentioned stylistic elements and the concaveness of the numbers and order of this instrument, the basis for it to be the legacy of Leonardo's work.

Leonardo himself offers some evidence for the constructing of a concave armillary sphere.

In Leonardo's Trattato della Pittura Leonardo uses the wordings "cosí nelle superficie sferiche e concave" (Langois, 1651) while referring to spherical bodies which receive as many different lights and shadows as there are different bodies encompassing them.

More significantly, in Codex Arundel page 227 recto, he lists a variety of colours, including a certain variety of red "aiorica", black chalk "nero in pietra", German blue "azzuro di Magnja", green "verde", wax to make the stars "ciera per fare le stell" and tin to mount the gold "stagno per apicare Por".

Furthermore, Leonardo refers to "vesta" when making reference to the stars "stell" (Garai, 2014). In Manuscript F page 57 recto dating from ca. 1508, the word stars is used for both stars and planets. This leads to the conjecture that Leonardo was preparing to use wax to construct planets for an armillary sphere in which he portrays the universal Ptolemaic order according to Ptolemy's Cosmography. The latter most likely inspired by Pliny whom Leonardo refers to as Plinio (Pedretti, 1977; Missinne, 2018). In the inventory of Leonardo in Codex Atlanticus, page 1109 recto a Spera, the abbreviated form of Armillary Sphere is listed (Pedretti, 1977), possibly the one Leonardo used in 1480 in his drawing Codex Atlanticus, page 5 recto.

One key question remains. Who was the French horologist who constructed the Jagiellonian Armillary Sphere?

\section{Who May Have Constructed the Jagiellonian Armillary Sphere?}

Based on a comparison of the content of the above-mentioned copper engraved 
globular gore map (formerly known as Tross Gores), kept at the New York Public Library, Estreicher proposed Louis Boulengier from Albi (Cabayé, 2001) as the maker of the Jagiellonian Armillary Sphere. This can be refuted as mentioned above based on the lack of cartographic accordance between the Jagiellonian and the Germanus world map. Babicz suggested Hans Dorn, scholar of Georg von Peuerbach (1423-1461) and Johannes Müller, known as Regiomontanus (1436-1476) in Vienna as the maker of the Jagiellonian. This lacks support because Hans Dorn was active only until the end of the $15^{\text {th }}$ Century and is known to have signed his instruments (Zinner, 1956).

As mentioned earlier, published research offers irrefutable evidence that Germanus was the author of the content of that map dating from 1507-1508 and that Louis Boulengier made the design (Estreicher, 1900). It may be a coincidence, but it was the flamboyant gothic style in the design throne on top of a copper engraving of an armillary disc which, like a detective research searching for a needle in a haystack, led to the interior of the Cathedral of Albi and to Louis Boulengier as its artistic designer (Missinne, 2015).

During this research one single name of a French clockmaker active in France during the lifetime of Leonardo da Vinci came up for a potential attribution on several occasions. His name is Julien Coudray (Dahl \& Gauvin, 2000) and he is known for his miniaturized clocks. In a French manuscript (Arch. Nat. kk. 289, fol. 444) it states that Coudray was paid 200 gold écus for two fine daggers, their gilts containing two gilt orloges destined for the King's use (Baillie, 1934). Some may recall his name from the highly expensive Swiss trademark, Julien Coudray 1518 in the ownership of IMH. No clock with his signature or markings has survived the Early Modern times. The reason for the attribution to the French royal horologist Julian Coudray is fourfold.

Firstly, his is the only contemporary French clockmaker's name that fits with the period of the construction of the instrument between 1507-1510.

Secondly, he worked as a royal clockmaker in Bloys (Blois) as early as 1504 for two subsequent French kings: Louis XII and Francois I.

But most importantly, Coudray shared with Leonardo da Vinci a rather important pivotal client and trésorier of the above-mentioned French kings. This Royal treasurer was active in Italy at the beginning of the $16^{\text {th }}$ Century. The name of this very wealthy Frenchman is Florimond Robertet.

In the inventory of Robertet (MS. Transcribed in Mém de la Sco. Nat. Des Antiquaires de France, 3e Série, t. X. 1868) dating from August $4^{\text {th }} 1532$ his widow stated: "I attach value only to the large one, merely of gilt copper, that my husband had had made; it shows all the stars and the celestial signs and motions which he understood perfectly (Baillie, 1934)." The large size is compared to the small watches "monstre" listed in this inventory.

Thirdly, Robertet was the client who had this timepiece made: an armillary sphere showing all the stars and the celestial signs, containing a clock. It also refers to the fact that he perfectly understood the celestial signs and motions, as Leonardo did. Finally, it refers to gilt copper and not to gilt brass. 
It is not certain when this armillary sphere became part of the collection of Robertet, but I believe that this offers some important evidence for the astronomical instrument containing the copper Lenox Globe which Julien Coudray may have copied to 2/3rd and which ended up in the Jagiellonian Museum in Cracow. Some circumstantial evidence may be the fact that Robertet's name is engraved on an astrological copper print Motus none Spere discovered together with the above-mentioned world map from c. 1507 attributed to Germanus, containing the Phrase: AMERICA NOVITER REPERTA in an unauthorized French copy of Waldseemüller's Cosmographiae Introductio of 1507. This is Florimond Robertet, the powerful and art-loving bibliophile, ambassador, treasurer of Louis XII and of Francis I King of France (1494-1515) also named Florimond $1^{\text {st }}$ Robertet d'Alluye (1458-1527). From King Louis XII, Robertet had received the royal command to attract Leonardo da Vinci to France (Missinne, 2015).

While in Northern Italy, it was Florimond Robertet who ordered a small painting of a Madonna and a Child from Leonardo. To substantiate the interest of Leonardo and Robertet in Astronomy and scientific instruments, I refer to a recent discovery presented at an international conference on Cartography in Rome in December of 2019.

This so-called Lansdowne Virgin of the Yarnwinder does not depict a textile Yarnwinder but a Jacob staff, also known as a cross-staff (Acidini, Bellucci, \& Frosinini, 2014), which is an astronomical instrument (Kanas, 2019). This is an item that commonly appears in the representation of astrologists. It symbolizes the activities upon which the practice of the astrologist might draw (Dunn et al., 2018). So, not only is there a common client but, so it seems, a common interest in astronomical instruments such as an armillary sphere and astrological practice. The fact that the Lenox Globe was discovered in 1854 by Richard Hunt on the Quai Voltaire near the Palais Royal in Paris is only of circumstantial importance.

Fourth, in 1560, a certain Jean Naze of Lyons constructed an armillary instrument containing a clock, kept at the Orangery Planetarium in Kassel, reminiscent at first sight of the artistic style of the Jagiellonian instrument but with cartographic information from a later date of Johan Schoener's Globe from 1523 and Oronce Fine's map from 1531. This instrument reflects the miniaturization of Julien Coudray. The globe has a diameter of only $6.6 \mathrm{~cm}$ and a scale of ca. 1:200.000.000. Significant in the cartography of this French globe of Jean Naze is the naming of a large island in the Indian Ocean. This large island bears the name of Regio Pathalis (King, 2009). The name and geographical location are based on Pliny and Bacon (King, 2011). Roger Bacon quoted Pliny erroneously with regard to the geographic location of the Regno Patalis, locating it South of the Capricorn (Van Duzer, 2007). The interest in this discourse lies in the fact that Bacon's southern relocation may be reflected in the large anonymous island engraved on the da Vinci Globe and cast on the Lenox Globe. Until now it was unknown what may have inspired Leonardo to engrave this large island South of 
the Capricorn in the East Indian Ocean. The Florentine genius writes the name of Rugieri Bacon in Codex Arundel (BL Arundel 263) page 71 verso.

The name of patalis regio is, as described based on Bacon, mentioned on a large unknown arctic territory connected to the enlarged Asian continent in a circular $15^{\text {th }}$ century world map included in a French educational book. The title: La salade nouvellement imprimee, laquelle fait mension de tous les pays du monde et du pays de la Sibylle auec la figure pour aller au mont de la belle Sibille, et aussi la figure de la mer \& de la terre et plusieurs belles remonstrances originally dating from 1440 to 1444 and newly printed in 1521.

The author was the French satirical writer Antoine de la Sale (c. 1386 - c. 1460) (Stallard, 2010).

The investigation of the throne of an astrolabe Inv. Nr. AST 057 dating from 1553 attributed to Jean Naze at the National Maritime Museum in London corroborates the Jagiellonian artistic influence on Naze's astrolabe. The throne by Naze comprises of two half-length mythical creatures (Figure 10).

The lower part of their bodies ends in a scroll which flanks a centrally positioned artistic shield containing an oval. The central world globe has become an oval, and the meaning of the scroll has been personified into two mermen, half-length male mythical creatures. In ancient Greek art, Triton was the sea-god depicted as a half-man and half-fish merman. In this case, it may be a depiction of Glaucus, the prophetic sea god who came to the rescue of sailors in storms.

The Italian nocturnal and horary quadrant Inv. 2503 at the Galileo Museum constructed by Girolamo della Volpaia dating from ca. 1568 seemingly makes use of the early Renaissance "wave" design by Leonardo with a globe between two lengthy mannerist scrolls. This type of "wave" design in a throne is also reflected by Christoph Schissler in his armillary sphere dating from 1560 .

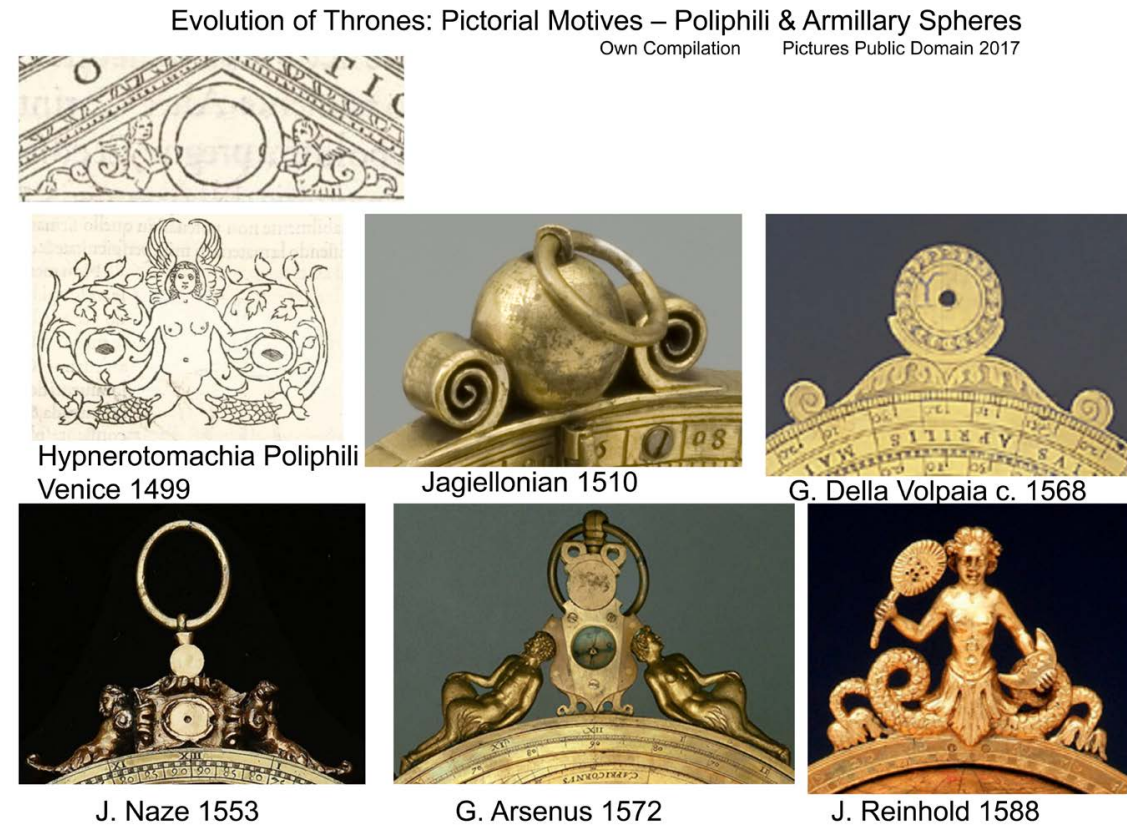

Figure 10. Evolution of thrones: Pictorial motives-Hypnerotomachia Poliphili. 
The kind of personification of the scrolls in mermen is also the case for the astrolabe Inv. 1103 in the collection of the Galileo Museum in Florence designed by Gualterus Arsenus dating from 1572. In the foregoing, the merman turns into a half-naked male and a female satyr reclining against a mannerist shield. The French astrolabe dating from ca. 1595 at the British Museum Reg. Nr. 1897, 1118.1 by Philippe Danfrie is influenced by the Arsenius school in Louvain (Van Cleempoel, 2006). It uses two lengthy foliate scrolls carrying two naked, reclining male satyrs with their characteristic buck feet supporting a swiveling suspension disc in the shape of an armillary sphere and a quadratum nauticum in the throne on the mater.

Finally, this type of personalized artistic adaption of what started as a clear design of a pair of scrolls adjacent to this globe is also visible in the globe by Reinhold Johann. In his brass gilt terrestrial table globe at the Maritime Museum in Greenwich Inv. GLB0022, the throne turns into a mermaid holding the symbols of the Sun and the Moon.

The above comparison (Figure 10) of the artistic evolution of the thrones of several $16^{\text {th }}$ Century instruments shows what was originally a scroll and a sphere turned into a reclining half-fish merman reflecting the divinity of the waters and satyrs reflecting the untamed and terrifying powers of nature (Cooper 2013). The variation of Thrones in the Astronomicum Caesareum, a printed work by Peter Apian (ca. 1495-1552) (Apian, 1540) is a prime example of Mannerism.

Leonardo thinks in pictures (Missinne, 2018). This kind of perception is much profounder in iconographic content than a symbolic form (Stewering, 2000). To think in terms of pictures and from this perspective to write appears to be part of a divine ability (Krüger, 2004).

The question arose if it would be possible to discern the source of this pictorial idea from a certain source?

Upon the suggestion of Univ. Prof. Dr. Fritz Koreny, I analyzed the contemporary publication called the Hypnerotomachia Poliphili, also known as "The Dream of Poliphilus" believed to be the work of the Dominican Priest Francesco Colonna (1433-1527) from Venice. The reason is that the Hypnerotomachia, first published in Venice in 1499, functioned, apart from the diverse literary and artistic impulses that emanated from her, as a design book full of ideas for new artifacts.

There is a fragment of the Magna Porta, the Monumental Portal in the Poliphili which is of interest to take a careful look at. It forms a part of an esoteric encryption in this influential Renaissance aesthetics publication (Krüger, 2004), in the form of a statuary that decorates the pediment/tympanum, that is, the temple facade. The author Colonna writes about a conspicuous and marvelous composition. Indeed, below $\triangle \mathrm{IO} \Sigma$ AIГIOXION two giants in the form of satires holding a sphere can be discerned.

These satyrs are giants, the offspring of Gaia (Earth) and a race of great strength and hubristic aggression, known for the Gigantomachy (Gigantomachia), 
their battle with the Greek Gods. These satyrs are fully human in form, with legs that become coiled serpents as can be seen also on the monumental Gigantomachy frieze of the second century BC known as the Pergamon Altar (Oettinger, 2000).

Clearly, the designer of the throne of the Jagiellonian in contrast to the ones from a later date than 1510 did not copy or follow the design of the fragment of the Magna Porta contained in the Hypnerotomachia Poliphili.

Therefore, it may be concluded that the contemporary iconographic meaning of the two scrolls is contained in a newly developed design in this case one of whirlpools which reflects the kinetic untamed energy and power of nature and of the oceans in particular.

These spirals are life-giving whirlpools from which, for example, Hesiod said Aphrodite had arisen; the foregoing being the source of life and natural energy, even magic (Cooper, 2013). For Leonardo, as depicted in his Manuscript K, water is the source of life and the way by which nature becomes transformed (Galluzzi, 2018). Leonardo calls whirlpool "retroso", which means backwards, in Manuscript F, page 13 verso. The iconography of the world sphere, the cosmic egg, in between the two scrolls means perfection, the primordial form which contains all the possibilities of all the forms as Plato's animus mundi, the soul of the world (Cooper, 2013).

What follows is based on the foregoing inventory and may not be all that speculative, but it certain from his personal inventory that Florimond Robertet did have a keen interest in astronomy. This may have encouraged him to request a Renaissance technological transfer in the form of a copy of the Lenox Globe instrument to be constructed on a reduced scale by a young French clockmaker, Julien Coudray, active at the court in Blois. This may be corroborated from the evidence from the phrase of his widow in stating: "that my husband had had made".

The discovery of the reversed crescent Moon adjacent to the capital letter C which appears to be a monogram of Julien Coudray, clockmaker active for the French Royal Court in Blois.

One may never know, but clearly, the inviting sea route open to the West depicted on the Jagiellonian Globe may have convinced the French King Francois I to help finance the French expedition under the command of Gionvanni da Verrazzano in 1524. This brave decision was only five years after the death of Leonardo in 1519 and shortly after the return of the expedition of Magellan led by Juan Elcano in 1522. Magellan unintentionally chose the longest sea route. $\mathrm{He}$ and especially his financiers were convinced that the fabulous riches of the spice islands were only 600 miles away from Brazil. This was printed in a German woodcut pamphlet dating from 1515 (Haebler, 1895). It is in the original manuscript, written in Madeira 12 October 1514 and now kept at the Fugger Archive, a prime source of "fake news" for one of the first printed newspapers in the world. 
This was during the lifetime of Julien Coudray. The purpose of the expedition of Giovanni da Verrazzano was to discover new lands in China. Based on the open sea route on the available cartographic material, including the da Vinci and the Lenox Globe, he ended up in New York which he, in honor of the French king born in Cognac, baptized Nouvelle Angoulême.

Coincidentally, the location in this port of call by Giovanni da Verrazzano is only a few miles away from the New York Public Library, the place where the Lenox, a copper cast by Leonardo and the contemporary American cartographic birth certificate by Donnus Nicolaus Germanus, are kept.

\section{Conclusion}

The research on the toponyms unmistakably proves that the Jagiellonian Globe from 1510 is the younger and smaller sibling of the Lenox and the da Vinci both dating from 1504.

Furthermore, the analysis of the Jagiellonian Armillary Sphere offers key evidence based on the indirect approach that a French horologist copied an Italian Renaissance instrument. The compelling and convincing arguments and chronological evidence are offered by the orthography, cartography, nomenclature, dimensions and iconography of the instrument and the unique cartography of the terrestrial globe contained at its center.

It seems highly probable that the horologist may have been given the order to make a replica of the Italian instrument by Florimond Robertet, a client of Leonardo da Vinci, upon which he decided to make a 2/3rd scale of the layout. In making the copy, the French horologist added the latest cartographic news in the form of the terminology "America noviter reperta", which he most probably used from a small woodcut booklet printed in August 1509. He hereby baptized America erroneously on a large uninhabited island in the Southern Indian Ocean. The foregoing allows us to limit the date of the Jagiellonian instrument to after 1507 as a terminus post quem. The specific didactic scheme of the universal armillary sphere, in addition to the whirlpools adjacent to the orb, bears a visual signature of Leonardo: Leonardo thinks in pictures.

In conclusion, I can summarize that there is compelling evidence that the French horologist, most probably Julien Coudray, active for the successive French Kings in Blois, was influenced by stylistic Renaissance and didactical aspects used by Leonardo da Vinci. These included: the mirroring of the Roman numerals and the order of the hour band on the Equator reflecting the concaveness of the object. Leonardo thereby applies the Vitruvian discerning design and reverses ancient Greek philosophy.

In addition, Leonardo's design as contained in the world-like cylindrical object in double current using scrolls in Codex Leicester, page 22 recto unequivocally supports the underlying kinematic meaning of the life-giving and untamed nature of the whirlpools in the throne of the armillary sphere. At first one may be sceptic about the visual connection between the design of the throne of the 
armillary sphere and Leonardo, but the comparative analysis of the contemporary instruments and Leonardo's own drawings prove otherwise.

Finally, Leonardo's hand appears in the design of the Northern Italian heraldic plates, the triangular shape and content of the throne. The anonymous large mountainous island reflecting the Regio Pathalis of Pliny and Bacon is used in the cartography of the da Vinci, Lenox and Jagiellonian Globe. No other map or globe is known other than the three foregoing to depict this feature. In contrast, the horologist may not have been influenced by the highly rivalrous and competitive mercantile culture of Renaissance Florence, and so he indifferently omits the key Indian spice Port of Caliqut. The clockmaker was relying on the authority of caster of the Lenox as an inter-model and the genius Leonardo da Vinci who created his own globe.

As the Lenox Globe forms the model for the Jagiellonian Globe, of which no other sample exists, this substantiates, in addition to the above-mentioned stylistic elements and the concaveness of the numbers and order of this instrument, the basis for it to be the legacy of Leonardo's work.

The most important element substantiating the fact that the anonymous Jagiellonian Armillary Sphere is based on published physical, pictorial, chemical, cartographic, mathematical, calligraphic, bibliographical, iconographic and narrative evidence offered in the research on the da Vinci Globe.

Lastly, there is a bibliographical reference from 1532 to an astronomical clock instrument similar to the Jagiellonian Armillary Sphere in a contemporary inventory in France of the famous Florimond Robertet, notorious client of Leonardo da Vinci, which may have been used as a model for the French royal clockmaker and miniaturist Julien Coudray French Renaissance artists, architects and horologist alike used the advanced Italian Renaissance as a scholarly role model for replication and adaptation.

It is as if when looking at the Jagiellonian Armillary Sphere from 1510, without its later stand, one can open a window onto history to see from what perspective Leonardo, while in Florence in 1504, constructed the blueprint for the Jagiellonian Armillary Sphere.

The Jagiellonian instrument has not received much serious scholarly attention. Further interdisciplinary research is hereby recommended and so it seems, a beginning has been recently made.

In 2018, the New York Public Library decided to scan the Lenox Globe. More recently, the same team under the leadership of Gregory Heyworth, Associate Professor of English and Textual Science at the University of Rochester (N.Y.), Director of the Lazarus Project who scanned the Lenox Globe scanned the Jagiellonian Globe in 2020. Lazarus, a highly appropriate name for the resurrection of the misinterpreted Jagiellonian Armillary Sphere.

Cecilia Gallerani, depicted as the Lady with an Ermine, a famous painting of Leonardo at the Czartoryski Museum in Cracow, is now joined in a very short walking distance by a contemporary scientific instrument reminiscent of Leo- 
nardo's Genius.

\section{Acknowledgements}

I would like to thank the following people who have assisted in the making of this research possible, either in providing expert advice, making suggestions or doing the hard job of proofreading. They included:

Harvard Univ. Prof. Dr. Owen Gingerich, Dott. Marisa Addomine, Dr. Geert Verhoeven, Dr. Armin Schlechter, Dr. Andreas Zajic, Expert Eric Delalande, Dr. Robert J. King, Dr. Malgorzata Taborska, Univ. Prof. Dr. H. Matis, Dr. Günther Oestmann, Dr. David A. King, Dr. Maurits Biesbrouck, Expert Jan Degraeve, Prof. Dr. Vivian Forbes, NASS Secretary General Steve Lelievre, Mumec Director Fausto Casi, Dr. Georg Zotti, Dr. Roel Nicolai, Dr. Jean-Francois Gauvin, Dr. Hannah Marcus, Prof. Dr. Koenraad Van Cleempoel, Dr. Johan Ickx, Mag. M. Banas from the Collegium Maius, Dr. Rüdiger Fuchs, Curator Mag. Martina Jurstak, Sarah Cavalier, Curator Dr. Karsten Gaulke, Leonardo expert Dr. Luca Garai, Prof. Dr. Gregory Heyworth, Dr. Marco Versiero, Alessio D’Andrea, Archivar Franz Karg, David Missinne BA, Curator and Director of Adler Collections Pedro M. P. Raposo DPHIL, HSM Oxford Head of Research, Teaching and Collections Dr. Stephen Johnston, Expert Pascal Cotte, Sabina Bernacchini, Prof. Gary Peters, Univ. Prof. Dr. Edoardo Villata, Dr. Carla Glori, Certified Expert University Prof. Dr. Fritz Koreny, Art Research expert in engravings James Constable, History of Cartography Expert Luis A. Robles Macías and numerous others.

\section{Conflicts of Interest}

The author declares no conflicts of interest regarding the publication of this paper.

\section{References}

Acidini, C. R., Bellucci, R., \& Frosinini, C. (2014). New Hypotheses on the Madonna of the Yarnwinder Series. Leonardo da Vinci's Technical Practice: Paintings, Drawings and Influence. In M. Menu (Ed.), Proceedings of the Charisma Conference. Paris: Hermann.

Ames-Lewis, F., \& Bednarek A. (1992). Decorum in Renaissance Narrative Art. London.

Apian, P. (1540). Astronomicum Caesareum. Ingolstadt: Arnt von Aych.

Babicz, J. (1970). Globe d'Or Jagellon du début du XVIieme Siècle. International Coronelli Society for the Study of Globes, Der Globusfreund 18/20.

Baillie, G. H. (1934). The First Printed Book about a Clock. Watch and Clock Maker, No 77, Vol. VII.

Bambach, C. C. (2003). Leonardo da Vinci, Master Draftsman. New York: The Metropolitan Museum of Art; New Haven and London: Yale University Press.

Bertele, H. (1961). Globes and Spheres. Lausanne.

Cabayé, O. (2001). An Unrecognized Humanist: Louis Boulengier of Albi, Mathematician, Cosmographer, and Geographer. Revue Historique, No. 619, 671-693. 
https://doi.org/10.3917/rhis.013.0671

Caglioti, F., \& De Marchi, A. (2019). Verrochio Master of Leonardo. Venezia: Marsilo.

Clark, K., \& Kemp, M. (2015). Leonardo da Vinci. UK: Penguin.

Cooper, J. C. (2013). An Illustrated Encyclopaedia of Traditional Symbols. London: Thames \& Hudson.

Cotte, P., \& Simonot, L. (2020). Mona Lisa's Spolvero Revealed. Journal of Cultural Heritage, 45, 1-9. https://doi.org/10.1016/j.culher.2020.08.004

Dahl, E. H., \& Gauvin, J. F. (2000). Sphaerae Mundi, Early Globes at the Stewart Museum. Septentrion. Montreal: McGill-Queen's University Press.

Dalché, P. G. (2010). Avant Behaim: Les globes terrestres au xve siècle. Humanisme et Découvertes Géographiques, No. 58, 43-61. https://doi.org/10.4000/medievales.5964

Dekker, E. (2000). Globes at Greenwich: A Catalogue of the Globes and Armillary Spheres in the National Maritime Museum, Greenwich. Oxford: Oxford University Press.

Dekker, E. (2007). Globes in Renaissance Europe. In D. Woodward (Ed.), History of Cartography. Chicago \& London: University of Chicago Press.

Dekker, E., \& van der Krogt, P. (1993). Globes from the Western World. London.

Dunn, R., Ackermann, S., \& Strano, G. (2018). Heaven and Earth United. Instruments in Astrological Contexts. Leiden/Boston: Brill. https://doi.org/10.1163/9789004381438

Estreicher, T. (1900). Globus Biblioteki Jagiellońskiej z początku wieku XVI, w Krakowie. Nakładem Akademii Umięjetności.

Fairey, E., \& Caradonna, A. (2010). Sphaera Mundi: The Medicis and the Armillary Sphere. Collection Catalog.

Fehrenbach, F. (2002). Leonardo da Vinci, Natur im Uebergang. Munich: Wilhelm Fink Verlag.

Ferrari, U. (2020). Leis. Forme dello Scudo.

Frank, L., \& Delieuvin, F. (2019). Léonard de Vinci: Louvre 2019. Paris : Hazan/Louvre éditions.

Franke, J. N. (1884). Jan Brożek (J. Broscius) akademik krakowski 1585-1652. Jego życie $i$ dzieła, ze szczególnem uwzględnieniem prac matematycznych. Ze źródeł Rękopiśmiennych.

Galluzzi, P. (2006). La Mente di Leonardo, Nel Laboratorio del Genio Universale. Florence: Giunti.

Galluzzi, P. (2018). Water as Microscope of Nature. Leonardo da Vinci’s Codex Leicester. Florence: Giunti.

Gamba, E. (2010). Proviamo a rileggere il "Doppio ritratto" di Luca Pacioli. In F. M. Cesaroni, M. Ciambotti, E. Gamba, \& V. Montebelli (Eds.), Le tre facce del poliedrico Luca Pacioli. Age Arti Grafiche Editoriali. Quaderni del Centro Internazionale di Studi Urbino e la Prospettiva.

Garai, L. (2014). La Festa del Paradiso di Leonardo da Vinci. Milano: La Vita Felice Ed.

Glori, C. (2020). The Cartouche of the Double Portrait of Luca Pacioli and Pupil. The da Vinci's Enigma Decode.

Guillaume, M. Ch. (1892). La Nature, No. 996.

Haebler, K. (1895). Die” Neuwe Zeitung aus Presilg-Land” im Fürstlich Fugger'schen Archiv. In Zeitschrift der Gesellschaft für Erdkunde zu Berlin. Nr. 30. Berlin.

Hessler, J. W., \& Van Duzer, C. (2012). Seeing the World Anew. Washington DC: Library of Congress.

Hessler, J., Karnes, C., \& Wanser, H. (2008). Who printed Waldseemüller: Watermark 
Evidence from the 1507, 1513 and 1516 Maps. Washington DC: Library of Congress.

Isaacson, W. (2017). Leonardo da Vinci. New York: Simon \& Schuster.

Kanas, N. (2019). Star Maps. Switzerland: Springer Nature. https://doi.org/10.1007/978-3-030-13613-0

Kemp, M. (1977). Leonardo and the visual Pyramid. Journal of the Warburg and Courtauld Institutes, 40, 128-149. https://doi.org/10.2307/750993

Kemp, M. (2006). Seen Unseen. Art, Science, and Intuition from Leonardo to the Hubble Telescope. Oxford: Oxford University Press.

King, R. (2009). The Jagiellonian Globe, a Key to the Puzzle of Javela Grande. The Globe (Journal of the Australian and New Zealand Map Society), No. 62, 1-50.

King, R. (2011). Regio Patalis: Australia on the Map in 1531? The Portolan, 82.

King, R. (2014). Tadeusz Estreicher and the Jagiellonian Globe. The Globe (Journal of the Australian and New Zealand Map Society), No. 75, 16-28.

Krüger, R. (2004). Wanderungen auf der Nekropole der an Liebe Verstorbenen: Memoria als intermediale Inszenierung in Francesco Colonnas "Hypnerotomachia Poliphili" (1499). Kritische Berichte. Zeitschrift für Kunst- und Kulturwissenschaften. Band 31 Nr. 1.

Kugel, J. (2002). Spheres. The Art of The Celestial Mechanic. Paris: J. Kugel.

Kulski, J. K. (2019). Leonardo da Vinci \& the Pacioli Code. Perth: SP J. Kulski.

Langois, G. (1651). Trattato Della Pittura. Paris.

Laurenza, D. (2006). Figino and the Lost Drawings of Leonardo's Comparative Anatomy. The Burlington Magazine, 148, 173-179.

Lohrmann, D., \& Kreft, T. (2018). Codex Madrid I: Maschinenbau und Maschinenelemente, Band I. Wien: Böhlau.

Macagno, E. (2002). Leonardian Fluid Mechanics "Libro dell'Acqua”, IV, IIHR Monograph No. 122 IIHR - Hydroscience \& Engineering. Iowa City: The University of Iowa College of Engineering.

Marinoni, A. (1954). I rebus di Leonardo da Vinci raccolti e interpretati, 171 fogli. Firenze: Olschkiht.

Metcalf, A. C. (2020). Mapping an Atlantic World, circa 1500. Baltimore, MaD: JHU Press.

Missinne, S. (2013). A Newly Discovered Early Sixteenth-Century Globe Engraved on an Ostrich Egg: The Earliest Surviving Globe Showing the New World. The Portolan, 87, 8-24.

Missinne, S. (2015). America’s Birth Certificate: The Oldest Globular World Map: c. 1507. Advances in Historical Studies, 4, 239-307. https://doi.org/10.4236/ahs.2015.43019

Missinne, S. (2018). The Da Vinci Globe. Newcastle upon Tyne: Cambridge Scholars Publishing.

Missinne, S., \& Verhoeven, G. (2019). Leonardo Depicted America: Misread as the Moon. Advances in Historical Studies, 8, 139-147. https://doi.org/10.4236/ahs.2019.84011

Oettinger, A. (2000). The Hypnerotomachia Poliphili: Image and Text in a Renaissance Romance. PhD Dissertation, Charlottesville, VA: University of Virginia.

Pedretti, C. (1977). The Literary Works of Leonardo da Vinci, Volume I. Berkeley, CA: University of California Press.

Pingree, D. (2009). Eastern Astrolabes. Historic Scientific Instruments of the Adler Planetarium (Volume II). Chicago, IL: Adler Planetarium and Astronomy Museum. 
Rombai, L. (2003). Leonardo Genio e Cartografo. La rappresentazione del territorio tra scienza e arte. In A. Cantile (Ed.), Firenze: Instituto Geografico Militare.

Sarma, S. R. (2019). A Descriptive Catalogue of Indian Astronomical Instruments-Abridged Version. Hamburg: Tredition GmbH.

Savage-Smith, E. (1985). Islamicate Celestial Globes. Their History, Construction, and Use. Washington DC: Smithsonian Institution Press.

Seemann, H. J. (1929). Die Instrumente der Sternwarte zu Marägha nach den Mitteilungen von al 'Urdī. Erlangen.

Stallard, A. J. (2010). Antipodes to Terra Australis. PhD Thesis, Brisbane: The University of Queensland.

Stevenson, E. L. (1921). Terrestrial and Celestial Globes. New Haven, CT: Yale University Press.

Stewering, R. (2000). Architectural Representations in the "Hypnerotomachia Poliphili" (Aldus Manutius, 1499). Journal of the Society of Architectural Historians, 59, 6-25. https://doi.org/10.2307/991560

Taborska, M. (2020). Globus Jagiellonski z Kolecji Muzeum Uj. Alma Mater, 217, 114-119.

Van Cleempoel, K. (2006). Astrolabes at Greenwich: A Catalogue of the Astrolabes in the National Maritime Museum, Greenwich. Oxford: Oxford University Press.

Van Duzer, C. (2007). Cartographic Invention: The Southern Continent on Vatican MS Urb. Lat. 274, Folios 73v-74r (c.1530). Imago Mundi, 59, 193-222. https://doi.org/10.1080/03085690701301012

Van Duzer, C. (2020). Martin Waldseemüller's 'Carta marina' of 1516: Study and Transcription of the Long Legends. Berlin: Springer. https://doi.org/10.1007/978-3-030-22703-6

Vasari, G. (1965). The Lives of the Artists: A Selection. Harmondsworth: Penguin.

Vogel, K. A. (1996). Armillarsphäre und Frühe Globen vor 1492, International Coronelli Society for the Study of Globes. Der Globusfreund 43/44.

Wells, F. C. (2013). The Heart of Leonardo. London: Springer. https://doi.org/10.1007/978-1-4471-4531-8

Winternitz, E. (1942). Quattrocento Science in the Gubbio Study. The Metropolitan Museum of Art Bulletin, 1, 104-116. https://doi.org/10.2307/3257029

Wittkower, R. (1964). Principi architettonici nell'età dell'Umanesimo. Torino: Einaudi.

Zakrzewska, M. N. (1965). Catalogue of Globes in the Jagiellonian University Museum. Trans. Franciszek Buhl. Cracow.

Zinner, E. (1956). Deutsche und niederländische astronomische Instrumente des 11. - 18. Jahrhunderts. München.

Zöllner, F. (2003). Leonardo da Vinci's portraits: Ginevra de’ Benci, Cecilia Gallerani, la Belle Ferronière, and Mona Lisa. Dudzik, S. (Ed.), Sztuka I Kultura 4. Torun.

Zöllner, F. (2010). Bewegung und Ausdruck bei Leonardo da Vinci. Leipzig: Plöttner Verlag. 


\section{Appendix A}

Comparative analysis Toponyms of the Jagiellonian, the Lenox and the da Vinci globe.

\begin{tabular}{|c|c|c|}
\hline JAGIELLONIAN (1510) & LENOX (1504) & DA VINCI (1504) \\
\hline \multirow{2}{*}{ 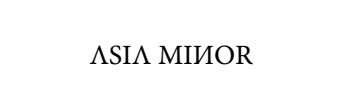 } & ASIA MIN & ASIA MIN \\
\hline & OR & OR \\
\hline \multirow{2}{*}{ GEIL $\Lambda$} & SEIL & SEIL \\
\hline & AN & AN \\
\hline \multirow{2}{*}{ AR $\Lambda \mathrm{BI} \Lambda \mathrm{FEIIX}^{*}$} & ARABIA FEL & ARABIA FEL \\
\hline & IX & IX \\
\hline DRАИGI & $\mathrm{xxx}$ & $\mathrm{xxx}$ \\
\hline \multicolumn{3}{|l|}{$\Lambda И \Lambda$} \\
\hline \multirow[b]{2}{*}{$\mathrm{xxx}$} & SARMATIA TRA IM AVM & SARMATIA TRA IM AVM \\
\hline & ASIATICA & ASIATICA \\
\hline T $\Lambda$ RT $\Lambda$ RI $\Lambda$ & SARMATIA & SARMATIA \\
\hline $\mathrm{C} \Lambda \mathrm{R}$ & CAR & CAR \\
\hline $\mathrm{M} \Lambda$ & MRN & MRN \\
\hline ИІА & IA & IA \\
\hline POL $\Lambda$ RTIC VC & CIRC VLVS AR TICVS & CIRC VLVS AR TICVS \\
\hline CIRCVLVS EQVIИOCIAL* & $\mathrm{xxx}$ & $\mathrm{xxx}$ \\
\hline FLO $\Lambda \mathrm{C}$ & LOA C & LOA C \\
\hline $\mathrm{PR}$ & PR O & PR O \\
\hline \multirow{2}{*}{$\mathrm{O}$} & VIN & VIN \\
\hline & CI A & CI A \\
\hline${ }^{\star} \mathrm{MVREVLI}^{\star}$ & $\mathrm{xxx}$ & $\mathrm{xxx}$ \\
\hline \multicolumn{3}{|l|}{${ }^{*} \mathrm{RE}^{\circ *}$} \\
\hline $\mathrm{xxx}$ & SC HI TIAIN * ESPESIL & SC HI TIAIN * ESPESIL \\
\hline IRC $\Lambda И I \Lambda$ & $\mathrm{xxx}$ & $\mathrm{xxx}$ \\
\hline \multicolumn{3}{|l|}{ P $\Lambda$ RTHI $\Lambda$} \\
\hline${ }^{\star} \mathrm{C} \Lambda \mathrm{NFV}^{*}$ & $\mathrm{xxx}$ & $\mathrm{xxx}$ \\
\hline SACHARV & SACHARVM & SACHARVM \\
\hline$M *$ REGIO & REGIO & REGIO \\
\hline \multirow{2}{*}{ IИD I $\Lambda$ IИTR $\Lambda$ * G $\Lambda$ ИES } & INDIA INTRA & INDIA INTRA \\
\hline & CANGEM & CANGEM \\
\hline 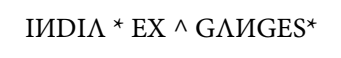 & INDIA EXT RA & INDIA EXT RA \\
\hline IИ D I $\Lambda$ * DES & IN DIA & IN DIA \\
\hline \multirow{2}{*}{ ERTA } & DE SE & DE SE \\
\hline & RTA & RTA \\
\hline
\end{tabular}




\section{Continued}

\begin{tabular}{|c|c|c|}
\hline $\mathrm{xxx}$ & IN DIA ORIENTALIS & IN DIA ORIENTALIS \\
\hline \multirow{2}{*}{$\mathrm{xxx}$} & IN DIA SVPERI & IN DIA SVPERI \\
\hline & OR & OR \\
\hline SIN GVI & $\mathrm{xxx}$ & $\mathrm{xxx}$ \\
\hline $\mathrm{I} \Lambda \mathrm{V}$ & $\mathrm{xxx}$ & $\mathrm{xxx}$ \\
\hline \multicolumn{3}{|l|}{$\Lambda^{*}$} \\
\hline \multicolumn{3}{|l|}{$\mathrm{M} \Lambda \mathrm{I}$} \\
\hline \multirow{3}{*}{$\mathrm{xxx}$} & MESO & MESO \\
\hline & POTA & POTA \\
\hline & NIA & NIA \\
\hline $\mathrm{MO} \Lambda \mathrm{B} \Lambda \mathrm{R}$ & MO ABIO REGNO & MO ABIO REGNO \\
\hline MANGI & $\mathrm{xxx}$ & $\mathrm{xxx}$ \\
\hline $\begin{array}{l}\text { OCE } \Lambda \text { NVS * IN DICVS * } \\
\text { MEREDIONALIS* }\end{array}$ & $\mathrm{xxx}$ & $\mathrm{xxx}$ \\
\hline PEV & $\mathrm{xxx}$ & $\mathrm{xxx}$ \\
\hline \multicolumn{3}{|l|}{ TA } \\
\hline 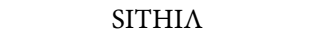 & $\mathrm{xxx}$ & $\mathrm{xxx}$ \\
\hline PERSI $\Lambda$ & PER SIA & PER SIA \\
\hline SCHITIA & SCHITIAEXT & SCHITIAEXT \\
\hline $\mathrm{EX}^{\wedge}{ }^{\star} \mathrm{IM} \Lambda \mathrm{V}$ & RAIAMVM & RAIAMVM \\
\hline SINA* $^{*}$ & SINARVM & SINARVM \\
\hline $\mathrm{RVM}^{\star} \mathrm{RE}^{\circ}$ & REGIO & REGIO \\
\hline $\mathrm{T} \Lambda$ & TA & TA \\
\hline \multirow[t]{2}{*}{ PRO } & PR & PR \\
\hline & O B & O B \\
\hline \multirow[t]{2}{*}{$\mathrm{B} \Lambda \mathrm{N}$} & A & A \\
\hline & $\mathrm{NA}$ & $\mathrm{NA}$ \\
\hline
\end{tabular}

\begin{tabular}{ccc}
\hline TROPIC C $\Lambda$ NCRI & TROPIC V SCANCRI & TROPIC V SCANCRI \\
\hline CIRCVLVS C $\Lambda$ PRICORNI & $\mathrm{xxx}$ & $\mathrm{xxx}$ \\
\hline ZIPAG RI (blurred, heavy corrosion) & ZIPA N & ZIPA N \\
\hline$\Lambda$ NC $\Lambda$ (blurred. small island) & CR I & CR I \\
\hline ARBET (blurred. heavy corrosion) & $\mathrm{xxx}$ & $\mathrm{xxx}$ \\
\hline IVDE $\Lambda$ & $\mathrm{xxx}$ & IVDAE \\
\hline $\mathrm{xxx}$ & IVDAE & A IN (pasted over) \\
\hline $\mathrm{xxx}$ & ANF VROIN & HC SVNT \\
\hline $\mathrm{xxx}$ & HC SVNT & DRACONES \\
\hline
\end{tabular}




\section{Continued}

\begin{tabular}{|c|c|c|}
\hline $\mathrm{xxx}$ & BACTRIANA & BACTRIANA \\
\hline \multirow{2}{*}{$\mathrm{xxx}$} & CIR TE & CIR TE \\
\hline & NA & NA \\
\hline $\mathrm{xxx}$ & VARP R & VARP R \\
\hline $\mathrm{xxx}$ & INDVS & INDVS \\
\hline $\mathrm{xxx}$ & IRCINIA & IRCINIA \\
\hline $\mathrm{xxx}$ & PARTHIA ARIA & PARTHIA ARIA \\
\hline \multirow{2}{*}{$\mathrm{xxx}$} & GE NGEM & GE NGEM \\
\hline & FLVVIVM & FLVVIVM \\
\hline $\mathrm{xxx}$ & SIMA RVM S ITVS & SIMA RVM S ITVS \\
\hline $\mathrm{xxx}$ & TRAIM AVM & TRAIM AVM \\
\hline $\mathrm{xxx}$ & ALBANIA & ALBANIA \\
\hline \multirow{2}{*}{$\mathrm{xxx}$} & SERICA & SERICA \\
\hline & REGIO & REGIO \\
\hline $\mathrm{xxx}$ & SIRIA & SIRIA \\
\hline $\mathrm{xxx}$ & GARIENI & GARIENI \\
\hline $\mathrm{xxx}$ & CALIQVT & CALIQVT \\
\hline $\mathrm{xxx}$ & ASSIA & ASSIA \\
\hline $\mathrm{xxx}$ & CACOBATE & CACOBATE \\
\hline \multirow{3}{*}{$\mathrm{xxx}$} & ARM & ARM \\
\hline & ENI & ENI \\
\hline & A & A \\
\hline$\Lambda$ MERIC $\Lambda{ }^{*}$ NOVITER ${ }^{*}$ REPERT $\Lambda$ & $\mathrm{xxx}$ & $\mathrm{xxx}$ \\
\hline TERR $\Lambda$ & T ERRA & T ERRA \\
\hline DEBR & DEBRA & DEBRA \\
\hline$\Lambda \mathrm{ZIL}$ & ZIL & ZIL \\
\hline${ }^{\star} \mathrm{MONDVS}^{*}$ & MVNDVS & MVNDVS \\
\hline${ }^{*} \mathrm{NOVVS}^{*}$ & NOV VS & NOV VS \\
\hline TERR $\Lambda$ * SAN & TERRA SAN & TERRA SAN \\
\hline $\mathrm{CTAE}^{*} \mathrm{CR}$ & $\mathrm{CTAE}^{*} \mathrm{C} \mathrm{R}$ & $\mathrm{CTAE}^{*} \mathrm{C} \mathrm{R}$ \\
\hline \multirow{2}{*}{ VCIS $^{*}$} & $\mathrm{VC}$ & $\mathrm{VC}$ \\
\hline & IS & IS \\
\hline IS $\Lambda$ BELL $\Lambda$ & ISABEL & ISABEL \\
\hline \multirow{2}{*}{$\mathrm{SP} \Lambda \mathrm{N}$} & SP AGNOL & SP AGNOL \\
\hline & LA & LA \\
\hline${ }^{*} \Lambda \mathrm{FFRIC} \Lambda^{*}$ & AFERICA & AFERICA \\
\hline
\end{tabular}




\section{Continued}

\begin{tabular}{|c|c|c|}
\hline \multirow{3}{*}{$\Lambda \mathrm{E}$ GI PT } & $\mathrm{E}$ & $\mathrm{E}$ \\
\hline & GIP & GIP \\
\hline & TVS & TVS \\
\hline $\mathrm{xxx}$ & GETVLIA & GETVLIA \\
\hline \multirow{2}{*}{ LIB I $\Lambda$} & DES ERTA LIB & DES ERTA LIB \\
\hline & IA & IA \\
\hline LIB I $\Lambda$ * IVTERIOR & LIBIA * INTEROIR & LIBIA * INTEROIR $^{*}$ \\
\hline MERO $\Lambda$ E GIPT $\Lambda$ & MEROVE INSV LA & MEROVE INSV LA \\
\hline И $\Lambda$ VRIT $\Lambda$ & MA CVSI & MA CVSI \\
\hline $\mathrm{P} \Lambda \mathrm{L} V \mathrm{DES}$ & PA L VDES & PA L VDES \\
\hline И?I LLVIS & NI LI & NI LI \\
\hline $\mathrm{M} \Lambda$ & MADA & MADA \\
\hline $\mathrm{D} \Lambda$ & GASCAR & GASCAR \\
\hline \multicolumn{3}{|l|}{$\mathrm{G} \Lambda \mathrm{SC} \Lambda \mathrm{R}$} \\
\hline $\mathrm{xxx}$ & C VERDE & C VERDE \\
\hline $\mathrm{xxx}$ & R GRADE & R GRADE \\
\hline $\mathrm{xxx}$ & ZAMOR & ZAMOR \\
\hline \multirow{2}{*}{$\mathrm{xxx}$} & C D EBONE & C D ÉBONE \\
\hline & SPERAN ZA & SPERAN ZA \\
\hline EVROP $\Lambda$ & EVROPA & EVROPA \\
\hline \multirow{2}{*}{ 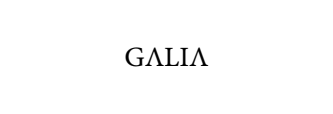 } & G A L & G A L \\
\hline & L IA & L IA \\
\hline IS & HISPA & HISPA \\
\hline $\mathrm{P} \Lambda$ & NIS & NIS \\
\hline \multicolumn{3}{|l|}{ ИІ $\Lambda$} \\
\hline \multirow{2}{*}{$\Lambda \mathrm{NG}$} & ANG & ANG \\
\hline & LIA & LIA \\
\hline I (Abbreviation for Ireland) & $\mathrm{xxx}$ & $\mathrm{xxx}$ \\
\hline $\operatorname{IT} \Lambda \mathrm{LI} \Lambda$ & ITALIA & ITALIA \\
\hline $\mathrm{S} \Lambda \mathrm{R}$ & SARMAT & SARMAT \\
\hline $\mathrm{M} \Lambda \mathrm{CI} \Lambda$ & IA & IA \\
\hline IV (Unknown abbreviation) & $\mathrm{xxx}$ & $\mathrm{xxx}$ \\
\hline \multirow{2}{*}{$\mathrm{xxx}$} & SCO & SCO \\
\hline & TIA & TIA \\
\hline \multirow{3}{*}{$\mathrm{xxx}$} & EN GRON & EN GRON \\
\hline & EL PE A & EL PE A \\
\hline & $\mathrm{PE}$ & $\mathrm{PE}$ \\
\hline
\end{tabular}




\section{Continued}

\begin{tabular}{ccc}
\hline $\mathrm{xxx}$ & DATIE & DATIE \\
\hline $\mathrm{xxx}$ & RVSIAE & RVSIAE \\
& TANAIS & TANAIS \\
\hline $\mathrm{xxx}$ & CRE & CRE \\
& CIA & CIA \\
\hline $\mathrm{xxx}$ & GERMAN & GERMAN \\
\hline $\begin{array}{c}\text { Reversed Crescent Moon } \\
\text { followed by a C }\end{array}$ & IA & IA \\
\hline
\end{tabular}

$\mathrm{xxx}$ is used to indicate a blank. ${ }^{*}$ Word breaker/expiring triangle (Dreisporne). Spelling corrections of error of Estreicher (1900): GEIL $\Lambda$, DR $\Lambda$ ИGI $\Lambda И \Lambda$, ${ }^{\star} \mathrm{C} \Lambda N F V *$, MANGI, IV(unknown), possibly an engraving error. Lenox: Courtesy of the New York Public Library Rare Book Division, Astor, Lenox and Tilden Foundation Jagiellonian: Courtesy of the Lazarus Project 2020, Multispectral Imaging Project University of Rochester and the Jagiellonian University Museum in Cracow 2018. Own Compilation: @ Missinne, 2020. 